V. 12 N. 2

MAI-AGO 2016

ISSN 2317-6172

\title{
Juristas fora da curva: três perfis
}

OUTLIER JURISTS: THREE PROFILES

\author{
José Eduardo Faria
}

\section{Resumo}

0 trabalho apresenta três juristas heterodoxos, que fizeram a carreira acadêmica fora das categorias, métodos e esquemas convencionais do modelo de direito positivo prevalecente nas quatro primeiras décadas da industrialização brasileira (1940-1980). Forjado na tradição de uma teoria geral do direito de inspiração privatista e de caráter normativista, o pensamento jurídico então prevalecente não foi capaz de identificar e avaliar os problemas novos e os conflitos inéditos acarretados por um padrão de industrialização marcado pela intervenção do Estado na economia. 0 mérito dos três juristas heterodoxos foi, justamente, compreender criticamente a realidade social emergente e a litigiosidade advinda de um processo de urbanização, expansão demográfica e mudanças geo-ocupacionais.

\section{Palavras-chave}

Eficácia jurídica; positivismo; mudanças socioeconômicas; legitimidade; industrialização; democratização.

Recebido: 13.05 .2015 Aprovado: 31.08 .2015

DOI: http://dx.doi.org/10.1590/2317-6172201612

1 Universidade de São Paulo São Paulo - SP - Brasil

\section{Abstract}

This essay introduces critically three non-orthodox legal thinkers, who did their academic, political and professional careers independent from the conventional methods and cognitive scheme of positive law prevailing at the age of Brazilian industrial development (1940-1980). Under the influence of private law, that legal doctrine (legal positivism) wasn't able to identify and evaluate critically the new problems and social conflicts produced by a State pattern of industrial development. The merit of these three non-orthodox legal thinkers was to understand creatively the new social reality, the political litigation and the legal disputes underlying to the urbanization process, the demographic growth and geo-ocuppational changes of Brazil.

\section{Keywords}

Legal efficacy; positivism; social and economic changes; legitimacy; industrial development; democratic process. 

uristas fora da curva - por mais que essa expressão seja tecnicamente imprecisa no âmbito da Teoria do Direito e da Sociologia jurídica, ela é retórica e metaforicamente feliz para identificar ou apontar autores que não se submeteram ao peso do positivismo normativista que, exponenciado por um ecletismo vulgar, caracteriza o pensamento jurídico brasileiro. Um pensamento alicerçado nas tradicionais categorias e esquemas cognitivos do direito positivo, que se têm revelado incapazes de interpretar, avaliar e criticar os desdobramentos da industrialização do país, as imbricações cada vez mais complexas dos sistemas de governança públicos e privados e as novas fontes e modos de produção e legitimação do direito. Um pensamento que também tem se mostrado incapaz de detectar e compreender as realidades organizacionais e administrativas emergentes, por um lado, e os inexoráveis conflitos sociais decorrentes de um processo acelerado de migração, urbanização, expansão demográfica e mudanças geo-ocupacionais que marcou o país nas últimas décadas, por outro.

Se algo marca a formação de operadores jurídicos e do próprio pensamento jurídico brasileiro contemporâneo é a dificuldade das faculdades de direito mais antigas e tradicionais, integradas por juristas forjados na tradição de uma Teoria Geral do Direito de inspiração privatista e epistemologicamente frágil, de perceber os problemas novos e os conflitos inéditos acarretados para a sociedade pelo modelo de capitalismo tardio que caracteriza a Era Vargas. É, também, a dificuldade de compreender que as crises suscitam perplexidades, rompem consensos, provocam rupturas na ordem vigente, geram bifurcações na vida socioeconômica, exigem formulação de alternativas e impõem escolhas. Num contexto de desenvolvimento acelerado, em que esse tipo de pensamento jurídico organizado com base no princípio da legalidade reduz o direito ao direito estatal, os juristas fora da curva podem ser vistos como homens à frente de seu tempo e com trajetórias incomuns; como intelectuais que se colocam perante a história sempre duvidando de toda e qualquer certeza; como pensadores heterodoxos no plano doutrinário - ou seja, avessos ao formalismo normativista, conscientes de que a análise do direito não pode ser apartada da história e capazes de articular os novos saberes advindos de transformações econômicas, sociais e políticas, sem desprezar a riqueza de ideias, experiências e perspectivas de um período histórico em que as inovações no campo do conhecimento se convertem em fonte de valor econômico e poder social. ${ }^{1}$

Três pensadores podem ser identificados nessa perspectiva e nesse período histórico: Orlando Gomes dos Santos (1909-1988), Francisco Clementino San Tiago Dantas (19111964) e Raymundo Faoro (1925-2003). Um baiano, um carioca e um gaúcho. ${ }^{2}$ Catedráticos

1 Cf. Innerarity (2011).

2 Teria havido um jurista correspondente aos três em São Paulo, que àquela altura já era o maior centro econômico do país? Salvo melhor juízo, a resposta é negativa. Na Faculdade de Direito da USP, por exemplo, 
de direito civil em prestigiosas instituições públicas de ensino superior, como a Faculdade Livre de Direito da Bahia (hoje pertencente à Universidade Federal da Bahia) e a Faculdade Nacional de Direito (hoje pertencente à Universidade Federal do Rio de Janeiro), Gomes e San Tiago foram privatistas que, a partir de perspectivas intelectuais e influências doutrinárias distintas, souberam antever quatro fenômenos correlatos: (a) o desajustamento entre a estrutura social e a superestrutura jurídica surgido na transição de uma sociedade rural e de uma economia agroexportadora para uma sociedade urbano-industrial de massas; (b) a publicização e subsequente tecnicização e "humanização" e/ou "socialização" do direito privado, como decorrência do modelo de capitalismo tardio que marcou a industrialização brasileira, entre as décadas de 1940 e 1990; (c) a elevação da incidência administrativa e regulatória da esfera pública sobre a esfera privada, por meio do direito do trabalho e leis assistenciais; (d) a crescente democratização do direito, que consiste em fortificar os fracos, ou seja, compensar com superioridade jurídica a inferioridade social e economicamente mais fracos - os chamados hipossuficientes.

Por seu lado, em plena ditadura militar, Raymundo Faoro - que não seguiu a carreira acadêmica e foi o único dos três juristas fora da curva a alçar à Academia Brasileira de Letras soube distinguir legalidade e legitimidade, força e poder, dominação e autoridade, do mesmo modo como também teve a coragem de retomar a questão do impacto do liberalismo político tanto na formação dos juristas quanto nas discussões sobre o alcance e a funcionalidade do Estado de Direito. Em entrevista a mim concedida, disse ele:

A ideia de Estado de Direito não deve ser vista apenas pelo seu lado formal, como se bastasse um encadeamento lógico de normas dos mais diversos níveis. Também não pode ser aceita segundo os padrões tradicionais do positivismo jurídico, que considera uma legislação legítima apenas por ela ser legal. O Estado de Direito que imagino ultrapassa o âmbito do Direito Constitucional, pressupondo tanto o reconhecimento das liberdades públicas quanto uma ampla e efetiva participação social na produção legislativa. Mais do que a legalidade, o que me preocupa é a questão da legitimidade do direito, ou seja, o fundamento da obediência jurídica (FAORO..., 1978). ${ }^{3}$

poucos foram os privatistas e publicistas que tentaram compreender o Brasil com um olhar jurídico alargado. E os que se dedicaram a essa empreitada o fizeram basicamente a partir de marcos jurídico-institucionais - ao contrário de Orlando Gomes, San Tiago Dantas e Raymundo Faoro, que tinham como parâmetro uma abordagem histórica, com o foco na dinâmica das estruturas econômicas, de seus desdobramentos sociais e dos riscos políticos daí advindos.

3 A entrevista, bastante extensa, foi publicada pelo Jornal da Tarde, edição de 6 de maio de 1978, com o título "Faoro, em nome da lei". 
Quem estaria, então, produzindo um projeto político que fosse simultaneamente fundado nos ideais liberais e numa reflexão sobre o país? - indaguei, ao que respondeu Faoro:

Estamos saindo de um sistema autoritário, de natureza estamental, para um sistema de conflito de classes. Muitos grupos sociais já perceberam esse problema e têm procurado redimensionar seu papel na sociedade. No entanto, como permitir a todas as classes a redefinição de seus papéis em função de padrões democráticos e sem os riscos de conflitos de consequências imprevisíveis? Nesse sentido, a proposta liberal parece a melhor [...]. O que tenho em mente não é o liberalismo clássico, no sentido das liberdades de, mas um liberalismo moderno, no sentido das liberdades para. Um liberalismo mais ligado ao povo, do qual ele estava distanciado. Costuma-se dizer que o liberalismo tradicional morreu quando, na verdade, ele superou-se - termo esse que deve ser encarado em perspectiva hegeliana. As velhas liberdades se transformaram em novas liberdades, de tal forma que hoje elas não mais conteriam os vícios de antigamente. O que salvou o liberalismo foi sua extensão a todas as forças da sociedade civil, as quais lhe deram atualidade e consciência política. (FAORO..., 1978).

Deflagrada a partir da Revolução de 30, a industrialização brasileira decorreu de um conjunto de condições e fatores internos e externos. Cada etapa desse processo assegurou a base sobre a qual a etapa seguinte se firmou. A industrialização também foi precedida por acirrados debates sobre o papel regulador do Estado, sobre dirigismo vs. liberalismo econômico, sobre planejamento vs. livre-iniciativa, sobre industrialização vs. livre-cambismo, ${ }^{4}$ por um lado, e sobre a formação e o funcionamento das estruturas sociais brasileiras, por outro. Além de retomar as questões da centralização do poder e do aumento da capacidade regulatória da União, esses debates trataram do papel das elites e das massas no desenvolvimento social. Versaram sobre os desdobramentos políticos e ideológicos da decadência das oligarquias rurais e da expansão das massas urbanas. Apontaram as incongruências, tensões, dilemas e polarizações que afetavam a sociedade brasileira. Discutiram as alternativas para a remoção dos obstáculos estruturais constituídos pelo Brasil arcaico e para a proteção das instituições do Brasil burguês nascente. Questionaram a efetividade e a legitimidade das formas democráticas e não democráticas de organização e exercício do poder. E, além dos diagnósticos, entreabriram ainda variados e distintos prognósticos sobre a evolução das estruturas de poder. ${ }^{5}$

4 Ver $A$ controvérsia do planejamento na economia brasileira, coletânea da polêmica travada por Eugênio Gudin e Roberto Simonsen (1977), que foi desencadeada pela apresentação das primeiras propostas formais de planejamento da economia brasileira ao final do Estado Novo.

5 Sobre o alcance e a importância desses debates, ver Santos (1978a, p. 18-57; 2006, p. 13-49). 
A tese vitoriosa, em favor de maior intervenção do Estado no domínio econômico, harmonizava-se desde o início da década com a política econômica adotada desde a ascensão de Getúlio Vargas ao poder - ou seja, desde o período da grande depressão mundial, provocada pela recessão americana. A opção por essa estratégia de industrialização teria decorrido muito mais de intuição política e de um certo pragmatismo voltado para a solução de problemas específicos de política econômica do que de um processo de planejamento que pensasse o desenvolvimento de modo articulado, através de orientação de longo prazo, políticas setoriais e metas de execução. Em outras palavras, não foi objeto de um plano, de diretrizes coerentes conscientemente estabelecidas, mas o resultado de ações e reações ditadas pelo momento político e pela conjuntura econômica. Várias circunstâncias forçaram o Estado a intervir de modo crescente no sistema econômico - desde a reação a crises internacionais e a vontade de controlar o capital estrangeiro no setor de serviços públicos, por exemplo, até o intento de industrialização rápida em determinados ramos de atividade. ${ }^{6}$ A partir daí, o Estado vai se afirmando como controlador, estimulador, planejador e até como árbitro dos conflitos nos quais também era parte. Mediante suas ações nos campos monetário e fiscal e interferências no sistema de preços, atuou como um aparato de proteção de várias atividades econômicas em face das vicissitudes dos mercados internacional e nacional.

As iniciativas e ações governamentais implicavam dessa maneira um forte dirigismo por parte do poder central, mediante a criação de mecanismos de controle dos mercados, a adoção de políticas de fomento da indústria nascente e a imposição de uma gama de medidas protecionistas, tais como barreiras tarifárias e não tarifárias, financiamentos, créditos com juro favorecido, subsídios e incentivos fiscais - além da participação direta em atividades produtivas, por meio de empresas públicas. Com isso, alicerçada num modelo de desenvolvimento com base na substituição de importações, a economia brasileira acabou crescendo para dentro, estabelecendo reservas de mercado e fechando-se aos fluxos do comércio internacional, por um lado, e não forjando um sistema relativo de preços por causa dos monopólios e oligopólios e da politização na fixação de preços, salários e tarifas, por outro.

Após o advento do Estado Novo, em novembro de 1937, o poder público diferenciou-se organizacionalmente e passou a estimular e promover a diversificação do aparato produtivo nacional, com o objetivo de ampliar sua capacidade industrial por meio da criação de empresas

6 Ver Baer, Kerstenetzky e Villela (1973); Abreu (1989a); e Bielschowsky (1988). A interpretação clássica da formação do capitalismo brasileiro e da política econômica adotada a partir da década de 1930 é a de Celso Furtado. Dos textos do autor, recorri neste trabalho a um paper que apresentou num seminário do Royal Institute of International Affairs, em Londres, publicado pela Revista Civilização Brasileira, Rio de Janeiro, 1965, v. 1, n. 1. Agradeço ao professor Rafael Diniz Pucci a localização desse exemplar - que não está digitalizado - na biblioteca da Faculdade de Economia e Administração da USP. 
estatais nas áreas de extração de minério de ferro, siderurgia, produção de motores e eletricidade, o que levou a uma mudança radical na identidade geo-ocupacional do Brasil no período de apenas quatro décadas. Em $1940,68,8 \%$ da população estavam no campo e 31,2\% nas cidades. Em 1980, 32,4\% da população encontravam-se no campo e 67,6\% concentravam-se em zonas urbanas e suburbanas. Evidentemente, essa conversão da sociedade rural numa sociedade urbana de massas em período bastante curto de tempo, exponenciada pela aceleração da produção industrial, provocou mudanças profundas nas estruturas sociais. Entre outros efeitos, a industrialização corroeu comportamentos sedimentados, quebrou hierarquias, diluiu expectativas comuns de justiça e alterou valores e pautas éticas. Também levou ao surgimento de uma teia de organizações não necessariamente políticas que articulavam e davam identidade coletiva aos agentes sociais, moldando suas atitudes e suas condutas e veiculando suas demandas. ${ }^{7}$ E ainda acarretou novos tipos de conflitos, pondo em xeque a capacidade do Estado de controlar a conduta das várias forças sociais, exigindo novos instrumentos jurídicos e superando a distinção entre direito privado e direito público.

\section{I}

Num cenário de mudanças socioeconômicas e político-institucionais tão intensas, rápidas e profundas como esse, a tensão entre a dinâmica social e a estática do direito exige uma Ciência do Direito nova, de horizonte alargado, sensível à história e aberta ao diálogo interdisciplinar. Também demanda a compreensão das relações fundamentais que os cidadãos têm de travar para assegurar as condições materiais de existência da sociedade. Requer, ainda, a redefinição do próprio papel do jurista. Aparece justamente aqui a acuidade de Orlando Gomes, cuja heterodoxia metodológica e cuja aversão ao conservadorismo o levaram a tomar consciência da importância da sociologia para compreender o direito como expressão de interesses materiais - condição necessária, ainda que não suficiente, para uma avaliação crítica das principais categorias e institutos do direito civil. Entre as décadas de 1950 e 1960, observava o jurista baiano:

As transformações sociais e econômicas determinam inevitável mudança de mentalidade - um povo ou comunidade que se desenvolve passa a adotar novos valores como fins da ação social. Essas transformações tendem a se institucionalizar, na medida em que o processo social e econômico procura na sua disciplina num novo sistema de normas. (GOMES, 1961, p. 19).

7 Cf. Santos (1979, p. 65). 
A realidade jurídica não pode ser desagregada ou apartada analiticamente da realidade social, dizia ele em artigos jornalísticos e ensaios sobre direito, consciente de que, quando mudam as situações, as categorias normativas e os mecanismos jurídicos têm de ser reformulados - ou seja, quando mudam as circunstâncias, muda o direito. A realidade social é histórica. Por isso, está em permanente mudança, o que leva a ordem em vigor a ser suplantada por outra, não sendo possível deter-lhe a marcha. Daí a importância de se identificar os princípios básicos e os fatores estratégicos que afetam o processo social, assinalava o civilista baiano. Somente os juristas com sensibilidade sociológica conseguem compreender com clareza a relação entre mudanças sociais e mudanças legais, entre mudanças econômicas e a expansão e diversificação das funções do Estado, dizia Orlando Gomes. "Não basta ao jurista estar atento às novidades de seu tempo - também é preciso reconhecer que o fator jurídico reage sobre o econômico, não sendo mero subproduto ou simples forma que se amolda ao conteúdo" (GOMES, 1961, p. 20), argumentava, depois de criticar a "pobreza do espírito inventivo dos juristas", especialmente daqueles que reduzem a investigação do fenômeno jurídico à legislação promulgada pelo Estado, e de lembrar que a realidade social e a experiência jurídica em hipótese alguma podem ser desprezadas, independentemente da orientação doutrinária ou do método empregado para a definição da ciência jurídica.

De todos os vícios que contaminam a técnica do direito, advertiu Orlando Gomes, num de seus mais sugestivos ensaios: ${ }^{8}$

nenhum mais grave, nas suas consequências, do que a deliberada dissimulação das transformações que agitam a ordem jurídica atual, na sua evolução irresistível. Por dois processos se vem conseguindo esse objetivo. O primeiro consiste na preservação do vocabulário jurídico, por sua defesa intransigente contra qualquer inovação terminológica. O segundo, no abuso das ficções. Conservando as mesmas palavras para designar situações diferentes, evita-se que a massa dos homens adquira consciência imediata das transformações sociais. (GOMES, 1955, p. 234-255).

8 O ensaio "A evolução do direito privado e o atraso da técnica jurídica", publicado no livro $A$ crise do direito (GOMES, 1955, p. 234-255). Esse livro é fundamental para este trabalho. A obra é uma coletânea de artigos e ensaios sobre o papel das classes sociais na formação do direito, o conteúdo de classe do direito civil, a humanização do direito privado, evolução do direito de propriedade, crise judicial e atraso da técnica jurídica. Com apenas oito ensaios, a primeira edição - bem menor que a definitiva foi publicada em 1945 por uma pequena casa editorial de Salvador, a Editora e Papelaria Vera Cruz. Nessa edição, Gomes afirmava já no primeiro parágrafo que “o verdadeiro jurista é aquele que não limita sua atividade à interpretação e à aplicação da lei”. A tarefa que lhe cumpre "desenrolar na investigação das fontes de elaboração do direito positivo. Sua missão [...] é de mais difícil desempenho, porque são todos os fenômenos sociais que precisam ser considerados sub specie juris" (p. 7). 
Criticando a estratégia de "disfarce da realidade" a que os juristas de formação positivista e normativista costumavam recorrer, "mascarando as novas soluções", convertendo a técnica jurídica na "apoteose do subterfúgio" e se deixando levar por um culto do texto legal e da vontade do legislador que os conduzia à "estatolatria”, disse ele:

A invariabilidade terminológica encerraria o direito numa cabine compensada, para manter artificialmente condições de vida que a pressão externa não permite mais. Os inconvenientes desse processo de dissimulação são manifestos. Primeiramente, porque é a consciência dessas transformações que impulsiona o pensamento jurídico, uma vez que sua verdadeira função consiste em assimilar aquelas aspirações sociais, que, por sua generalidade e intensidade, se impregnam de substância jurídica. Ocultar as transformações atrás dessa cortina de fumaça é pretender acompanhar a marcha da evolução do direito estugando o passo. Por fim, é inqualificável o deliberado propósito de camuflar a realidade pelo temor de declará-la. (GOMES, 1955, p. 234-255).

"A moldura do pensamento jurídico formalista tem admitido apenas os aspectos políticos da crise do direito e repelido seus termos sociais, apresentando a liberdade sob uma forma puramente abstrata, vazia de conteúdo social, aristocratizada num sistema de franquias”, argumentava Orlando Gomes (1955, p. 6), criticando sem meias palavras o consagrado jurista vienense Hans Kelsen e censurando o deslumbramento que então causava nos meios acadêmicos nacionais. Concluía ele:

Autores que interpretam artigo por artigo de um código têm uma visão deformada do sistema jurídico. Obrigados a uma particularização fatigante, reduzem o campo da visualização a um só preceito, perdendo a perspectiva do todo. O mister de que se ocupam está ao alcance de todas as mediocridades. Enxergam as árvores, mas não vêem a floresta. O resultado é fatalmente monstruoso [...] E o direito, que nos embates da vida evolui e se aperfeiçoa pela atividade criadora dos que o aplicam, converte-se novamente em uma ciência dedutiva. (GOMES, 1955, p. 6-7).

O que caracteriza essas "mediocridades" é sua incapacidade de entender que as instituições jurídicas não podem ser compreendidas por si, "devendo ser explicadas no conjunto das relações que definem as regras econômicas, a cujos fins gerais servem" (GOMES, 1961, p. 67-70).

Na dinâmica da sociedade, apontava o jurista baiano naquele e em outros livros que se seguiram, sempre acompanhando as transformações socioeconômicas do país, as novas instituições jurídicas tendem no início a se formar à margem do direito positivo. Das relações de produção emerge um paralelismo de orientações do direito e da economia manifestado 
no domínio das aplicações práticas - mais precisamente, da política que inspira a adoção e legítima aplicação de medidas econômicas e dos preceitos jurídicos.

A interdependência do econômico e do jurídico tem-se revelado por força desse paralelismo de orientações, em termos que atestam a sincronização do revisionismo jurídico ao processo de desenvolvimento econômico em vários setores da vida social. Mas como é fácil de compreender, o atraso do direito, considerado o ordenamento jurídico em seu conjunto, é inevitável, dado que a superação do subdesenvolvimento implica o rompimento das grades e o abandono de valores nos quais e sobre os quais assenta e se inspiram as instituições jurídicas. (GOMES, 1961, p. 67).

Em sua abertura para a sociologia e para a história com vistas à compreensão do "atraso do direito em relação aos fatos”, Orlando Gomes é ainda mais heterodoxo ao recorrer ao materialismo histórico e a categorias marxistas para analisar o impacto da economia na formação do direito, o conteúdo de classe do direito privado e o caráter instrumental dos sistemas jurídicos. Condicionadas pelas forças que se elaboram na superestrutura da sociedade, as normas jurídicas não podem ocultar seu conteúdo econômico. E mesmo as que aparentemente não o denunciam têm-no subordinado - afirmava o jurista baiano. Ainda que a condicionante econômica não seja a força modeladora única, autônoma, direta e imediata de todas as normas,

as instituições jurídicas não podem ser compreendidas por si mesmas, mas devem ser explicadas no conjunto das relações que definem os regimes econômicos a cujo fim servem [...]. O direito jamais pode se encontrar em um nível mais alto do que o estado econômico que a ele corresponde. (GOMES, 1961, p. 70, 84).

Ainda que a regra do direito não surja, se modifique ou desapareça ao sabor das circunstâncias econômicas das quais adote exatamente os contornos e siga os destinos efêmeros, observava Gomes, a ciência e a consciência de que se acha condicionada à estrutura material da sociedade são indispensáveis a uma visão realista do fenômeno jurídico.

Assim enquadrado no plano teórico, o "desajustamento entre a estrutura social e a superestrutura jurídica” envolve dois aspectos contraditórios. Ao mesmo tempo que é informado pelos processos sociais concretos que se desenrolam na sociedade, a superestrutura jurídica responde apenas indireta e parcialmente às mudanças ocorridas no nível da estrutura, resultando então na sobrevivência jurídica "em ambiente totalmente inadequado" ou num alargamento tal das bases da ordem jurídica que chega a sugerir a desarticulação das coordenadas ideológicas da ordem jurídica em vigor. A plasticidade de determinados institutos jurídicos que permanecem inalterados em seu aspecto formal, dos quais a propriedade e o contrato são os exemplos mais ilustrativos, representa um desafio para 
os pensadores jurídicos empenhados em encontrar a relação entre o jurídico e uma determinada ordem social - dizia Orlando Gomes. A seu ver, a elasticidade das reformas jurídicas encontraria seu ponto de ruptura nas tangentes em que se pode enquadrar o círculo dentro do qual se encerra a infraestrutura. O risco implícito nesse tipo de abordagem, advertia o autor, é produzir explicações simplificadoras - e, com isso, perder de vista a relevância da variabilidade do fenômeno jurídico, uma vez que as diferenças não podem ser explicadas por uma constante (isto é, pelo modo de produção capitalista que caracteriza as sociedades industriais).

Com base nesse esquema analítico, o jurista baiano também se propôs a discutir no decorrer da década de 1950 um tema que estaria no centro da agenda da sociologia jurídica três décadas depois e que seria objeto de minha tese de doutorado (FARIA, 1981): o desenvolvimento como imperativo político e o papel do direito como instrumento de desenvolvimento. Para tanto, recorreu a autores que os professores brasileiros de direito civil em sua esmagadora maioria jamais leram ou sequer ouviram falar, como Alberto Guerreiro Ramos, Celso Furtado, Florestan Fernandes e, principalmente, Ignácio Rangel, para quem coexistiriam no Brasil três estruturas econômicas - uma pré-capitalista, uma condicionada pelo capitalismo clássico de mercado e uma condicionada pelo capitalismo de Estado. Com base nessa literatura sociológica e econômica, Orlando Gomes entendia que o desenvolvimento não é um fim em si mesmo, mas

algo a ser promovido numa atmosfera de liberdades públicas, desconcentração de renda e justiça distributiva, por um lado, e de expressão material de interesses determinados, por outro. O processo de desenvolvimento se desdobra numa série de substituições do proibido pelo permitido e na incorporação do maior número de pessoas no círculo da produção jurídica. (GOMES, 1961, p. 25-29).

Dito de outro modo, Gomes acreditava na compatibilidade entre democracia e planejamento como instrumento de política econômica, um tema bastante polêmico à época. ${ }^{9}$

Nos países capitalistas, a ideia de planejamento surgira da necessidade de alcançar objetivos econômicos e sociais, após a crise de 1930, e do esforço de reconstrução do pósguerra, na década de 1950. A ideia era que o livre jogo de mercado, com escassa intervenção do Estado, não seria capaz de levar aos resultados almejados pela sociedade. Assim, com suas crises cíclicas, hiperinflação e desemprego, a instabilidade do sistema econômico estimulou a elaboração de modelos racionais de política econômica que permitissem dominar as forças econômicas e induzir os agentes produtivos em direção à alocação ótima

9 Ver, nesse sentido, Mindlin (1970) e Cardoso (1970). 
de recursos. No acirrado debate que se seguiu sobre o uso do planejamento como instrumento de desenvolvimento, liberais inspirados em Ludwig von Mises e Friedrich Hayek, por exemplo, alegavam que o mercado é o único mecanismo regulador da integração econômica e social e que o cálculo privado de custos e benefícios é o único critério para o estabelecimento de prioridades. Também afirmavam que, ao fixar objetivos e estabelecer metas para um determinado período de tempo, o planejamento aprofundava a centralização e burocratização das decisões econômicas, suprimia a liberdade de escolha e retirava das novas gerações o direito de determinar seus rumos. Por seu lado, pensadores de inspiração social-democrata, inspirados em Gunnar Myrdal e Karl Mannheim, afirmavam que somente um ator privilegiado como o Estado, em condições de intervir no mercado, em vez de se submeter a ele, poderia agir com base em objetivos e metas pré-fixadas. Diziam que o planejamento nada mais é do que um modelo teórico, que se propõe a organizar racionalmente o sistema econômico sobre a realidade. Alegavam, ainda, que a crença no automatismo do mercado e a teoria do laissez-faire nas decisões econômicas àquela altura da história havia sido perdida em caráter definitivo. E distinguiam planejamento coercitivo (obrigatório para a administração pública) e planejamento indicativo (optativo para a iniciativa privada). ${ }^{10}$

Intervindo nesse debate, Orlando Gomes lembrava que o desenvolvimento não é um processo exclusivamente condicionado por fatores econômicos, retomando assim a abordagem sociológica heterodoxa de que se valia para interpretar e analisar a chamada "crise do direito". Embora a infraestrutura econômica condicione os fatores extraeconômicos, estes influenciam a transformação social e o próprio processo de desenvolvimento econômico. A partir daí, a questão que o jurista passa a enfrentar é saber se o instrumental jurídico de sua época estava tão desatualizado a ponto de bloquear o desenvolvimento econômico e social. Assinalava Gomes:

Quem investigue os fatores do desenvolvimento econômico de determinada comunidade, verifica que não se circunscrevem ao campo da economia. Mesmo os que aceitam o condicionamento dos fatores extra-econômicos à infraestrutura da sociedade não podem negar a influência que exercem na transformação social e no próprio processo de desenvolvimento. Encarados os fatos sociais de um ângulo que os abarque em todas as perspectivas para o exame de uma sociedade em mudança, especialmente a que se esforça para liquidar o subdesenvolvimento, o que desperta a atenção é a assincronia das transformações. (GOMES, 1961, p. 9-10).

10 Um bom indicativo da importância desse debate é explicitado pela concessão do Prêmio Nobel de Economia tanto a Friedrich Hayek quanto a Gunnar Myrdal, em 1974. O texto clássico de Mannheim é Liberdade, poder e planificação democrática (1972). 
Já na conturbada passagem da década de 1950 para a de 1960, em que as reformas estruturais estavam na agenda de acirradas discussões sobre o caráter dependente da modernização econômica brasileira, Orlando Gomes voltou-se - como também ocorreria à época com San Tiago Dantas - para um horizonte programático muito mais amplo do que o dos professores de direito civil da época. As reformas agrária, fiscal, bancária, administrativa, eleitoral e universitária eram vistas, naquele momento histórico, como a cristalização de expectativas, reivindicações e recomendações que traduziam uma tomada de consciência coletiva da necessidade de concentrar esforços para romper inflexibilidades estruturais decorrentes do padrão de industrialização do país. O objetivo dessas reformas era preparar a economia para alcançar níveis mais altos de desenvolvimento e os desafios para sua implementação eram reforçar a capacidade de autotransformação do setor produtivo, definir as metas a serem alcançadas e estabelecer a ordem de prioridade na satisfação das necessidades da população.

Para um de seus formuladores, Celso Furtado, a ordem de prioridades sociais resultava de um novo conjunto de forças que se havia incrustado nas estruturas de poder. Ao justificar essas reformas, seja como superintendente da Sudene seja como ministro do Planejamento do governo João Goulart, Furtado dizia que os processos econômicos são passíveis de regulação consciente e que esta deveria ser exercida conforme os interesses coletivos. Também afirmava que, com a expansão do capitalismo e da subsequente concentração do poder econômico, os mecanismos autocorretivos do livre jogo do mercado não eram mais suficientes para evitar crises econômicas com alto custo social. Num discurso que alcançou grande repercussão, ao receber o título de Economista do Ano de 1962, ${ }^{11}$ conferido pela Ordem dos Economistas do Estado de São Paulo, Furtado asseverou:

As grandes tensões sociais que caracterizam a vida nacional parecem ter a causa principal no desajustamento entre as expectativas criadas pelo próprio desenvolvimento no conjunto da população e o limitado acesso permitido aos frutos desse desenvolvimento. As tensões não são causadas pelo sacrifício que o desenvolvimento exige, pois ele significa aumento de disponibilidade de bens e serviços para fins de consumo e investimento. Desenvolvimento é aumento do consumo e este não pode ser identificado com nenhuma forma de sacrifício. Ele se projeta na consciência do povo como um

11 A repercussão do pronunciamento foi basicamente causada pela afirmação de que as reformas estruturais somente seriam eficazes se, entre outros objetivos, dotassem o governo de instrumentos fiscais que lhe permitissem financiar investimentos públicos "com base em recursos recolhidos naqueles setores que estão sendo beneficiados pelo desenvolvimento". No debate sobre planejamento coercitivo e indicativo, democrático e autoritário, Furtado foi bastante influenciado por Mannheim, como reconheceu em A fantasia organizada (1985). 
estado de expectativa permanente de melhoria material. No caso do Brasil, o desenvolvimento criou condições para que se processasse inusitada concentração de renda, tanto geográfica como setorial e social. Daí o limitado acesso aos frutos do desenvolvimento. Como consequência, certos grupos da população estão sendo submetidos a efetivo sacrifício. (FURTADO, 1962).

Em sua abertura para um horizonte programático mais amplo na tumultuada década de 1960, e tocando nos mesmos temas - inclusive na questão do custo social do desenvolvimento - discutidos pelos defensores e pelos críticos das reformas de base, Orlando Gomes concentrou a atenção na radicalização nacional-populista, que vinha crescendo na mesma velocidade com que as tensões estruturais da economia e seus desdobramentos sociais iam sendo evidenciadas. Chamou atenção para o papel das instituições jurídicas na formação de capital produtivo, ao mesmo tempo que também apontou o papel limitado dos legisladores daquele período - que, a seu ver, não iam além de modelar o ritmo do desenvolvimento. ${ }^{12}$ Reconheceu que as estruturas formais do direito civil tenderiam a se estilhaçar com o advento das novas modelações normativas da economia. E ainda advertiu para o risco de o uso instrumental do direito resultar em hiperjuridificação ou inflação legislativa:

O fetichismo da lei como exuberante técnica social vem provocando a elefantíase da legislação no quadro clássico da propensão para legislar em função de interesses do Estado e do desenvolvimento econômico. As leis modificam-se dialeticamente, perdendo a qualidade pela quantidade. (GOMES, ${ }^{13} 1975$, p. 65 apud RAMOS; SILVA FILHO, 2015, p. 136).

Coordenador no início da década de 1960 de um malogrado projeto destinado a substituir o velho Código Civil de 1916, Orlando Gomes foi um autor prolífico que, recorrendo a abordagens heterodoxas e tomando como contraponto em seus artigos, ensaios e livros as disparidades regionais e as transformações sociais, políticas, econômicas e culturais do país, lançou um olhar inovador sobre os temas básicos tanto de direito civil - inclusive em matéria de família - quanto de direito econômico. Temas como contrato, propriedade privada, relação jurídica, obrigação, responsabilidade, culpa e risco, abuso de direito, negócio jurídico, títulos de crédito, contratos bancários, alienação fiduciária, leasing, franchising

Ver, nesse sentido, Ramos e Silva Filho (2015, p. 125-135). 
e repressão ao abuso do poder econômico, e também questões relativas ao reconhecimento de filhos adulterinos e dissolução de vínculo matrimonial, foram analisados e discutidos com base na ideia de que uma interpretação de fatos sociais se dá por meio de uma interpretação de seus "intermediários concretos”, a partir de sua base econômica (GOMES, 1955 , p. 49).

\section{II}

No mesmo ano em que Orlando Gomes publicou $A$ crise do direito, San Tiago Dantas deu uma aula inaugural que entraria para a história do pensamento jurídico brasileiro. Meses antes, Getúlio Vargas suicidara-se e a conjuntura estava marcada por grandes adversidades econômicas, graves tensões políticas, forte instabilidade militar e riscos de ruptura da ordem institucional. Originariamente um conservador esclarecido vindo da Ação Integralista Brasileira, e que aos 28 anos escrevera uma tese de cátedra bastante original sobre um tema convencional de direito civil, ${ }^{14}$ ele começou chamando a atenção para a necessidade de valorização do dissenso, de relativização dos valores e de superação de visões estigmatizadas no campo político - isso numa exposição cujo tema era sobre a situação da educação jurídica no país. ${ }^{15}$ San Tiago prosseguiu denunciando a aversão das faculdades de direito a uma compreensão crítica de uma sociedade tão complexa e heterogênea como a brasileira. Afirmou que a crônica incapacidade dos cursos jurídicos de compreender o ambiente social, econômico, político e cultural em que estavam envolvidas os levava a formar operadores jurídicos incapazes de perceber que, quando as classes dirigentes são medíocres, a democracia representativa está em risco. Por fim, retomou uma indagação sobre a trajetória ou destino da Ciência do Direito que já discutira uma década e meia antes: "será seu papel histórico resistir e domesticar as inovações que surgem; ou procurar audaciosamente criar sobre elas uma ordem nova?" (DANTAS, 1979). ${ }^{16}$

Ao respondê-la, justamente quando se agravavam os conflitos de interesses econômicos entre os diversos segmentos sociais, San Tiago Dantas recorreu a Max Weber e Arnold Toynbee. Da principal obra do primeiro, Economia e sociedade, extraiu a ideia de burocracia

14 Conflito de vizinhança e sua composição, tese apresentada ao concurso para professor catedrático da Faculdade Nacional de Direito, realizado em 1939. Sob o trabalho em si, que inclui discussões metodológicas que não encontrariam paralelo nas três décadas seguintes, a realização do concurso e seus desdobramentos na política acadêmica, ver a extensa e cuidadosa biografia escrita por Dutra (2014, p. 401-408). “A educação jurídica e a crise brasileira”, aula inaugural da Faculdade Nacional de Direito, no Rio de Janeiro, em 1955 (DANTAS, 1955).

16 Em "Renovação do direito", discurso proferido na sessão comemorativa do cinquentenário da Faculdade de Direito da Universidade do Brasil, Rio de Janeiro, em 25 de outubro de 1941 (DANTAS, 1979). 
e a distinção entre dominação legal-racional, dominação tradicional e dominação carismática, para explicar a formação do direito público e o impacto do liberalismo político nas declarações de direitos e nas constituições modernas. "Pode qualquer política criar um direito, ou o direito em sua natureza técnica está comprometido com certos princípios éticos e sociais que colidem com alguns sistemas políticos e outros se harmonizam" (DANTAS, 1979) - indagou. Da principal obra do segundo, Um estudo de história, extraiu a análise entre a expansão e o declínio das sociedades, por um lado, e o aumento ou diminuição da eficácia dos meios de controle. "A causa imediata da expansão ou da decadência de uma civilização ou mesmo de um grupo social, como um Estado, reside respectivamente no aumento e na perda da eficácia de sua cultura, na capacidade ou incapacidade de criar e aplicar técnicas diversas de controle do meio físico e social”, (DANTAS, 1955) afirmou, depois de diferenciar classe dirigente e classe dirigida. ${ }^{17}$

“À classe dirigente compete encontrar e aplicar as respostas adequadas aos problemas sociais. É isso que lhe permite manter-se como dirigente, obtendo pela ação de um poderoso instinto social a adesão e a colaboração dos segmentos sociais restantes, a classe dirigida" (DANTAS, 1979), disse ele no início de sua célebre aula inaugural sobre a educação jurídica e a crise brasileira. E depois de apontar que a sociedade brasileira oferecia "um exemplo perfeito da crise determinada pela perda de eficácia ou poder criador da classe dirigente", afirmou o catedrático de direito civil da Faculdade Nacional de Direito:

Perca, porém, a classe dirigente a virtuosidade para resolver problemas, deixe sem resposta os desafios que lhe lança o meio social, e daí começam a fluir dois efeitos inelutáveis: para a sociedade, rompido o equilíbrio entre os problemas de controle que

17 A distinção entre classe dirigente e classe dirigida e as ideias de expansão e declínio das sociedades e de aumento ou diminuição da eficácia dos meios de controle é central no pensamento de San Tiago Dantas. Três anos depois da aula inaugural dada na Faculdade Nacional de Direito, portanto bem antes de seus textos sobre os impasses políticos entre as décadas de 1950 e 1960, ele a retomaria num ensaio sobre a sociedade brasileira na passagem do século 18 para o 19 e a influência exercida à época por José da Silva Lisboa, primeiro Barão e depois Visconde de Cairu: "Em lugar do quadro social de hoje (1958), dominado pelo contraste e mesmo pelo antagonismo, entre uma classe dirigente de eficiência declinante e uma classe popular em ascensão, o que se via era uma sociedade rarefeita, formada por um proletariado escravo, uma classe depauperada e escassa de assalariados livres, funcionários coloniais, comerciantes portugueses e retalhos de uma classe agrária, em que residia a maior força econômica e social do país" (DANTAS, 1962). Ao falar sobre Cairu, San Tiago afirmou que a maior lição da carreira dele teria sido a ideia de que "o destino individual só se realiza plenamente quando o homem logra, pelas suas energias e faculdades, entrar em equação com a sua mesma época, e exprimir na peripécia de sua própria vida a trama dos problemas em que se debate a sociedade a que pertence" (DANTAS, 1962). O ensaio, intitulado "Visconde de Cairu, protagonista de sua época", foi publicado no Jornal do Comércio, edição de 30 de março de 1958, e posteriormente incluído na coletânea Figuras do Direito, de 1962. 
os resolvem, inicia-se a decadência. E, para a classe dirigente, começa o processo de insurreição da classe dirigida, gradualmente desligada de sua subordinação mimética, e a transformação, às vezes lenta, mas a partir daí inevitável, da autoridade em privilégio. Pode suceder que a relação de equilíbrio entre os problemas e os meios de controle se rompa [...] por uma perda dos controles éticos sociais [...]. [Neste caso], a sociedade desaparece pela incapacidade de sua classe dirigente de manter a vida social sob a disciplina de normas éticas e jurídicas eficazes, que mantenham as atividades do grupo subordinadas aos ideais de sua cultura, conciliando justiça e eficiência, e impregnando de seus critérios éticos todas as formas de exercício da autoridade. (DANTAS, 1955, p. 450).

Para San Tiago Dantas, cujo pronunciamento foi realizado nove anos antes da eclosão do golpe militar de 1964, num momento de radicalizações desconexas, lutas personalistas, declínio da credibilidade do governo, crescente incapacidade do sistema político de funcionar e acentuada deterioração do quadro institucional, a falta de "ajustamento" entre a classe dirigente e a classe dirigida debilita o Estado de Direito, bem como reforça reacionarismos, processos antidemocráticos - enfim, toda espécie de autoritarismo. Uma passagem de sua aula, particularmente, dá a dimensão da perspicácia da análise:

a ruptura entre a classe dirigente e a classe dirigida, pela perda da capacidade da primeira de resolver problemas que se deparam à sociedade como um todo, traz, como fase sucessiva, o estado de disponibilidade da classe dirigida, ou seja, o clima de demagogia. Estabelece-se, então, a oportunidade do cesarismo. (DANTAS, 1955, p. 450).

Esse risco, sugeria San Tiago Dantas, que também era um bem-sucedido corporate lawyer, poderia ser afastado, entre outras medidas, por meio de uma educação jurídica menos formalista e, acima de tudo, aberta ao diálogo interdisciplinar. Ele conclui:

Pela educação jurídica é que uma sociedade assegura o predomínio dos valores éticos perenes na conduta dos indivíduos e, sobretudo, do poder público. Pela educação jurídica é que uma sociedade assegura o predomínio dos valores éticos perenes na conduta dos indivíduos e do poder público. Pela educação jurídica é que a vida social consegue ordenar-se segundo uma hierarquia de valores, em que a posição suprema compete àqueles que dão à vida humana sentido e finalidade. Pela educação jurídica é que se imprimem no comportamento social os hábitos, as reações espontâneas, os elementos coativos, que orientam as atividades de todos para as grandes aspirações comuns. (DANTAS, 1955, p. 452).

San Tiago aprofundou esses argumentos em seu último discurso, certamente o mais articulado de todos. 
Extenso e a um só tempo conceitual e programático, esse discurso foi concebido depois de uma vitória política - a bem-sucedida passagem à frente do Ministério das Relações Exteriores, entre 1961 e 1962 - e dois malogros: a rejeição de seu nome para primeiro-ministro no regime parlamentarista, em 1962, e a fracassada gestão um ano depois como ministro da Fazenda, quando permaneceu no cargo apenas cinco meses. ${ }^{18}$ Pronunciado no dia 25 de outubro de 1963 em evento ocorrido no Hotel Glória, no Rio de Janeiro, o discurso foi feito em agradecimento à homenagem que lhe foi prestada com a indicação de "Homem de Visão" daquele ano, num momento de forte descontrole monetário, desaceleração econômica, redução de investimentos, paralisia decisória do Executivo e do Legislativo e a acirrada polêmica em torno das "reformas de base" suscitada pela radicalização populista a ditadura militar seria instalada cinco meses depois, com a deposição do presidente João Goulart, a quem San Tiago servira duas vezes como ministro. O civilista carioca começou afirmando que não se pode ter uma visão do direito que o desconecte inteiramente da percepção da realidade socioeconômica e dos desafios de uma justiça distributiva, como ocorre nos casos do positivismo normativista, do mesmo modo como a questão do desenvolvimento também não pode ser vista exclusivamente por suas implicações econômicas, medido pela variação do Produto Interno Bruto (PIB) em matéria de investimentos. Na mesma linha de argumentação, sugeriu pensar o desenvolvimento por um viés político, capaz de refletir a condição da dignidade humana em um país com forte concentração de renda e, acima de tudo, com base num projeto nacional.

$\mathrm{Na}$ circunspecta simplicidade de seus argumentos estavam implícitas duas questões e uma advertência já tratadas na mesma época por um ex-colega de ministério e também pelo

18 A interpretação mais recorrente é de que o veto à indicação para primeiro-ministro e a oposição que o levou a ter de abdicar do Ministério da Fazenda decorreriam, entre outros fatores, da insatisfação de certos setores políticos e empresariais quanto a sua atuação à frente do Itamaraty, quando implementou o que chamou de "política externa independente". As razões, contudo, parecem mais complexas, como se depreende de um de seus discursos na Câmara dos Deputados: "chegamos a um momento em que certas necessidades se tornaram imperativas, Em primeiro lugar, o país não comporta mais uma administração sem rigoroso planejamento. Se queremos lutar contra a inflação, a primeira medida necessária é um balanço dos recursos de que dispomos e uma orçamentação honesta de nossas disponibilidades. Quem não dispõe de recursos ilimitados e tem diante de si problemas que os ultrapassam tem necessidade de planejar. Só um governo que se disponha a estabelecer uma ordem rigorosa de prioridades neste instante, e proporcionar a essas prioridades os recursos disponíveis, é que terá possibilidades de praticar uma política de contenção de preços. Precisamos, para evitar que a administração se projete nos vários setores de que se compõe, guiada apenas pelo poder de iniciativa de muitos ministros, concentrar a ação conjunta de um gabinete e, desta forma, criar para o país um governo de autoridade; de autoridade dentro da lei, de autoridade dentro dos limites traçados pelo Congresso, mas de autoridade sem incoerências e se desfalecimentos". O discurso foi pronunciado no dia 27 de junho de 1962 e seus desdobramentos políticos e econômicos são examinados criticamente por Abreu (1989b, p. 197-212). 
próprio Orlando Gomes: o problema da desigualdade social, por um lado, e os perigos do populismo, por outro. Com a clareza e objetividade habituais, declarou San Tiago:

Não é exato [...] que a democracia possa salvar-se como fórmula política apenas mediante o apego a certos ideais jurídicos, que deram expressão adequada, em outras décadas, a formas então válidas de supremacia social. Também não é certo que o futuro da democracia dependa apenas do desenvolvimento econômico, e que seu fortalecimento possa medir-se no crescimento da renda nacional ou do seu índice per capita. O crescimento da renda nacional, mesmo quando se processa a uma taxa superior à do aumento demográfico, pode reverter, graças à má distribuição social da riqueza em benefício de setores limitados da população, e agravar, em vez de atenuar, as tensões sociais internas, que comprometem a estabilidade das instituições democráticas e dela fazem um poderoso instrumento, não a serviço da reconciliação, mas a serviço da opressão. ${ }^{19}$ (DISCURSO..., 2004, p. 331).

$\mathrm{Na}$ realidade, embora o discurso tivesse um caráter basicamente programático, a sugestão de San Tiago de “pensar o desenvolvimento por um viés político” entreabria nesse ponto a experiência que enfrentara em sua passagem pelo Ministério da Fazenda, quando defendeu medidas de contenção orçamentária para deter a inflação, maior racionalização nas despesas de custeio, redistribuição da carga fiscal e a adoção de um cronograma adequado para a implementação do Plano Trienal elaborado por Celso Furtado. Como ministro da pasta mais importante do governo, San Tiago fora vítima do crescimento do populismo que, como é sabido, defende compromissos ambíguos e teses contraditórias, prometendo a massas urbanas sem estruturação definida o atendimento das aspirações imediatas sem, contudo, preocupar-se com as consequências que daí poderão resultar a médio e longo prazo. A radicalização populista foi o que se chamou à época de esquerda negativa, cujos líderes - como o deputado e exgovernador gaúcho Leonel Brizola, por exemplo - afirmavam que as reformas de base viriam "de qualquer maneira, pois (se for) perdida a oportunidade eleitoral, contaremos com a outra metade do povo brasileiro, aquela que não vota mas tem estômago". À esquerda negativa, que

19 O colega de ministério era Celso Furtado, que publicara pouco tempo antes um artigo na mesma linha de San Tiago, ainda que sob outra orientação doutrinária. "O retrocesso político não virá por acaso, mas como reflexo de pânico entre alguns grupos privilegiados confrontados com a crescente pressão social. Onde as estruturas são rígidas, impedindo adaptações graduais, essas pressões podem situar situações cataclísmicas, que conduzem a soluções de emergência ou a golpes preventivos", afirmou (FURTADO, 1963). O artigo foi publicado originariamente pela revista Foreign Affairs, na edição de abril de 1963, com o título "Brazil - what kind of revolution?", e republicado pelo jornal O Estado de S. Paulo na edição de 31 de março de 1963 - por ironia, exatamente um ano antes da eclosão do golpe e com o sugestivo título "Brasil - a situação pré-revolucionária". 
contava com apoio sindical, opunha-se a chamada esquerda positiva, integrada por Furtado e San Tiago, para quem as pressões populistas, além de corroerem o funcionamento das instituições básicas, eram incompatíveis com um projeto de desenvolvimento consequente, coerente e capaz de promover mudanças estruturais preservando valores morais e políticos fundamentais, como o respeito às práticas democráticas e às liberdades públicas.

Decorrem daí as conclusões e a advertência de San Tiago, em seu último e mais conhecido pronunciamento. No salão de eventos do Hotel Glória, disse ele:

Se nem a fidelidade aos princípios jurídicos nem o crescimento da riqueza bastam para preservar a democracia e adaptá-la ao mundo moderno, é indispensável aditar a esses dois fatores um terceiro: a reforma social. E é sobre as características, o alcance e os meios de processamento dessa reforma que o pensamento democrático, no Brasil e fora dele, não raro se torna evasivo. Dir-se-ia que para alguns a reforma social deve ficar propositadamente informulada, servindo mais de incentivo a reivindicações isoladas, que somam forças no sentido da violência, enquanto para outros é uma forma de contemporização consciente, destinada a servir de anteparo a um esforço de preservação das estruturas atuais.

Essas formas de deslealdade com a história não conseguem ser, porém, de duração prolongada. Se o pensamento democrático não for capaz de formular, em termos válidos e inteligíveis, seu esquema de reforma social, esta abrirá seu caminho antidemocraticamente, porque, no quadro das tensões internas da sociedade atual, as forças que aspiram a uma participação mais ampla nos benefícios da vida comum são superiores em intensidade às que procuram deixar em segundo plano essa ampliação, para se limitarem à defesa das chamadas garantias democráticas.

Toda contemporização ou insinceridade na abertura de um rumo eficaz de reforma social se liquida, desse modo, num reforço do processo antidemocrático e na debilitação a curto prazo da própria democracia. (DISCURSO.., 2004, p. 331).

O fortalecimento do processo antidemocrático de que San Tiago falava, nesse discurso, estava mais adiantado do que ele e expressiva parte da plateia supunham. As "situações cataclísmicas" já estavam criadas. O populismo tomava conta da cena pública e o regime democrático encontrava-se muito mais debilitado do que se imaginava. A perda de controle sobre a economia também já era evidente. E a ruptura institucional estava muito mais próxima do que se pensava.

\section{III}

Apesar de extensa, a passagem acima de San Tiago Dantas é fundamental para se compreender a contribuição de Raymundo Faoro ao tema. Como é sabido, ambos foram leitores de 
Max Weber, especialmente de seus textos sobre sociologia política, sociologia jurídica e sociologia econômica. Portanto, eram conhecedores da tipologia weberiana sobre racionalidade formal e racionalidade material, legitimidade formal e legitimidade substantiva, comando e obediência, ética de convicção e ética de responsabilidade e os três tipos de dominação - tradicional, burocrática e legal-racional. Com base nessa tipologia, San Tiago encarava a democracia representativa como uma engrenagem formal de normas e procedimentos, com base na regra de maioria, ao mesmo tempo que via nas reformas sociais a condição material de sua legitimidade. Já Faoro diferenciava legalidade, vista como um conjunto escalonado de leis estruturadas em função de um conceito de poder público, e legitimidade, o fundamento da obediência legal, criticando os ideólogos do regime militar que tentavam vincular esta última a políticas públicas eficientes e a resultados econômicos.

Quando o conheci, eu era jornalista do jornal O Estado de S. Paulo e do Jornal da Tarde e ele presidia o Conselho Federal da Ordem dos Advogados do Brasil (OAB), tendo vencido a eleição por 13 votos contra 11 dados ao seu opositor, o jurista e político baiano Josaphat Marinho (que, por curiosidade, fora aluno de Orlando Gomes em Salvador e, depois de formado, seu sócio em escritório de advocacia). Faoro e Marinho eram opostos em quase tudo. O primeiro vinha da vertente de juristas-políticos que criaram a OAB nos primórdios da década de 1930. Juristas-políticos são "homens de cultura e do direito público”, originários das elites tradicionais brasileiras e com acentuado poder de mando na sociedade. São homens com muita influência na vida pública e que provêm da linhagem de bacharéis oriundos de famílias tradicionais formados em escolas de direito criadas no século 19, como parte do esforço de construção do Estado nacional. ${ }^{20} \mathrm{Com}$ uma visão de mundo liberal-clássica, tiveram um papel decisivo na constituição de uma entidade que - longe de ser uma simples associação profissional, resultante da agregação de interesses de advogados atuantes em litígios interindividuais - fora originariamente pensada como um mecanismo de poder sobre a própria corporação e como instrumento de expressão e afirmação dos valores e opiniões da elite da categoria, os juristas-políticos. A OAB não se constitui assim numa entidade criada de baixo para cima, como expressão do conjunto diferenciado da profissão. Ela se constitui de cima para baixo, com base na iniciativa de uma elite homogênea em sua concepção de mundo. ${ }^{21}$

Dada a necessidade de ampliar sua legitimidade, o Estado saído da Revolução de 30 concedeu à $\mathrm{OAB}$, com o objetivo de obter seu apoio político, a prerrogativa de controlar imperativamente a categoria, de impor filiação compulsória e de estabelecer taxas independentes 
da vontade de seus membros. ${ }^{22}$ A partir das décadas de 1950 e 1960, com o avanço da industrialização e a emergência de novos tipos de litígios advindos com a urbanização, cresceu o número de faculdades de direito, aumentou o número de advogados militantes e acentuou-se a diferenciação funcional na operação cotidiana dos tribunais, o que levou a uma progressiva diluição da hegemonia e do prestígio dos juristas-políticos na OAB. Esse processo também foi acentuado pelas reivindicações dos setores emergentes das chamadas classes subalternas, já vistas no item anterior, bem como pelo subsequente surgimento dos chamados serviços legais inovadores, em cujo âmbito os interesses tutelados giram em torno de demandas coletivas ou individuais de repercussão coletiva, o que ajuda a organizar a população para a defesa de seus interesses e para a efetivação do acesso à Justiça, propiciando com isso conscientização e mobilização políticas. ${ }^{23}$ E foi aprofundado pela expansão das procuradorias estaduais e municipais, onde passaram a atuar profissionais de classe média tecnicamente muito bem formados, como é o caso de Faoro, procurador do Estado da Guanabara e um dos mais expressivos representantes da corporação. Com isso, a elite de juristas-políticos passou a sofrer concorrência de novos e influentes grupos de advogados, que mudaram a agenda de prioridades da categoria e geraram fortes tensões dentro da OAB - o que será particularmente explicitado após a vitória de Faoro sobre Marinho.

Raymundo Faoro assumiu o cargo em 1977, no mesmo período em que o Congresso foi posto em recesso e o "Pacote de Abril" foi editado pelo presidente Ernesto Geisel, mudando as regras do jogo eleitoral com o objetivo de afastar qualquer risco de vitória da oposição no pleito de 1978 . Nos anos anteriores, marcados pelo fracasso do $2^{\circ}$ Plano Nacional de Desenvolvimento - a pièce de résistance do governo no campo econômico, implodida pela alta extraordinária dos preços internacionais do petróleo - e por um crescente estremecimento das coalizões civil e militar que davam apoio ao regime desde 1968, por

22 Em outras palavras, como lembra Luiz Werneck Vianna, a OAB não é o resultado de um movimento da categoria, que no início da década de 1930 contava com cerca de 14 mil membros, mas de uma negociação entre o Estado e as elites do direito. Enquanto os juristas-políticos convalidaram as novas estruturas corporativas da administração pública, concedendo legitimação ao regime ainda em fase de imposição, o Estado concedeu poder à OAB, que passou a ser soberana em relação aos seus membros, constituindo a identidade com a força imperativa de um mandato público. Assim, “ao nascer a OAB já se erige como poder concorrente - e não apenas porque detém o império de regular sobre a categoria -, mas principalmente porque se arroga ao direito de guardiã e de fiscal de um bem público: a ordem jurídica” (VIANNA, 2015, p. 35-41).

23 Aos serviços legais inovadores, nos quais os advogados assumem uma postura política e conscientizadora, contrapõem-se os serviços legais tradicionais, que priorizam o atendimento de demandas individuais e são marcados por uma relação fria, técnica e vertical entre advogados e clientes, com os primeiros assumindo uma postura assistencialista e paternalista. Cf. Campilongo (1991). 
um lado, e pela incapacidade do governo Geisel de criar condições para a articulação de novas coalizões de apoio à sua estratégia de transição democrática "lenta, gradual e segura”, por outro, as facções mais radicais da ditadura vinham aumentando as prisões, ampliando a tortura de presos políticos nos porões de quartéis e carceragens policiais e criando situações de fato com o objetivo de desmoralizar aquela estratégia e aprofundar ainda mais a repressão. Ao mesmo tempo, o presidente dos Estados Unidos, Jimmy Carter, pressionava fortemente o regime a restabelecer as garantias fundamentais e estimulava movimentos sociais e entidades da sociedade civil a lutar pela reafirmação dos direitos humanos, exacerbando com isso a ira das facções mais radicais com relação a Geisel. ${ }^{24}$ Para os radicais do regime, afirmava então um analista da vida política nacional,

a insistência da oposição no debate sobre direitos civis e sobre torturas era apenas uma cobertura do propósito real de dividir os militares e, por essa via, restabelecer a anarquia que, de acordo com essa interpretação, fora responsável pela situação de recesso econômico em que o Brasil se encontrava antes de 1964. (SANTOS, 1978b, p. 122).

No período em que o conheci e definimos uma ação comum, Raymundo Faoro preparava um longo discurso para a sessão de abertura da VII Conferência Nacional da entidade, marcada para o dia 7 de maio de 1978, em Curitiba. Ele pretendia aproveitar a oportunidade para criar um fato político, retomando o tema do liberalismo com o objetivo de reivindicar o restabelecimento de garantias processuais e de criticar as alterações sucessivamente promovidas por meios arbitrários no ordenamento jurídico pelo regime militar, sob o pretexto de se legitimar não pelo direito positivo e pela Constituição, mas, sim, pelos resultados alcançados em matéria de crescimento econômico e de geração de emprego. ${ }^{25}$ Neste

24 O início do governo Geisel, em 1974, inflacionou as esperanças democráticas mais do que os compromissos por ele assumidos, em seus discursos, autorizavam. Essa inflação de esperanças iria ser, em parte, responsável pelo movimento compensatório de pessimismo nos anos seguintes - principalmente depois de Geisel ter afirmado que não abdicaria dos poderes extraordinários concedidos pelo regime, com base no Ato Institucional $n^{\circ} 5$, para coibir subversão e corrupção. Como lembram Wanderley Guilherme dos Santos (1978b, p. 120-121) e Lúcia Klein e Marcus Figueiredo (1979, p. 83-84), o que o governo Geisel propôs foi uma estratégia de distensão política baseada num cronograma bastante cauteloso, aceitando a suspensão da censura de imprensa, por exemplo, mas sem abrir mão dos instrumentos jurídicos autoritários e dos poderes que lhe permitiam regular o processo. Em outras palavras, Geisel teria reservado para si a função de termômetro da temperatura do chamado sistema revolucionário, adotando um mecanismo de consultas e avaliações periódicas da situação, em que ele próprio vinha a público ou se fazia ouvir formalmente por meio de seu ministro da Justiça, Armando Falcão, ou, informalmente, por seu chefe da Casa Civil, Golbery do Couto e Silva.

A ação comum consistia em entrevistas a serem publicadas nos dias anteriores ao do dia de abertura do 
ponto, mais precisamente, o que o jurista e historiador gaúcho radicado no Rio de Janeiro pretendia era questionar a modernização tutelada, que os ideólogos do regime chamavam de autoritarismo transicional.

Afirmavam esses ideólogos:

A legitimação do sistema revolucionário [...] está sendo lograda principalmente através de eficácia administrativa. Essa legitimação proveio inicialmente da contribuição do sistema para reversar uma situação (econômica) catastrófica, confirmou depois pelo impulso reformista (da máquina estatal) e está hoje reforçada pelo sucesso desenvolvimentista. (CAMPOS; SIMONSEN, 1974, p. 255).

Do outro lado do espectro político, o então presidente da OAB, com a sólida base intelectual da sociologia weberiana e da filosofia do direito alemã, destacava as influências da concepção liberal do Estado e suas representações jurídicas com base nos seguintes pressupostos: (a) qualquer norma pode ser instituída como lei reclamando e exigindo sua obediência por todos aqueles que estejam sujeitos à autoridade da comunidade política; (b) o direito constitui um sistema de regras abstratas que resultam de um estudo racional - consequentemente, a administração pública está condicionada pelas regras jurídicas, devendo ser dirigida em conformidade com certos princípios de formulação geral; (c) as pessoas que obedecem à autoridade legal assim constituída o fazem em caráter de cidadãos, e não de súditos, obedecendo à lei e não à vontade dos burocratas que as impõem; e (d) a burocracia, expressão formal da dominação racional do Estado, tende a estreitar ou restringir a funcio-

nalidade do Estado de Direito. ${ }^{26}$ Esses quatro pressupostos seriam a base de suas críticas ao regime militar e à ordem burocrático-autoritária por ele imposta.

Depois de abril de 1964, como é sabido, foi criada uma situação de fato altamente contraditória. Por um lado, o regime político advindo do golpe militar tentou em seus primórdios afirmar o ideal de um liberalismo político, mas carecia de bases sociais de sustentação.

evento da $\mathrm{OAB}$, a transcrição da íntegra de seu discurso pelo jornal $O$ Estado de S. Paulo e a publicação de um editorial em forma de apoio pelo Jornal da Tarde, então dirigido por Ruy Mesquita, de quem fui editorialista. O editorial foi publicado em 15 de maio de 1978. Devo a Carlos Guilherme Mota o estímulo para que superasse minha timidez e procurasse Faoro pessoalmente no Rio de Janeiro, para entrevistá-lo.

26 Ver, nesse sentido, Mommsem (1974); e Schluchter (1982). É importante lembrar que, além de respeitado analista do Estado patrimonialista brasileiro e de seus mecanismos de cooptação e conciliação, Faoro conhecia a teoria e a filosofia do direito alemãs - principalmente autores para quem o direito, antes de ser um sistema de normas, seria um instrumento de cultura. Ou seja, autores que concebiam o direito não como simples fato social, mas como fator cultural - um conjunto de valores colocado a serviço da justiça e da dignidade do homem. 
Nas relações dos novos dirigentes com a sociedade estabeleceu-se um vácuo político-representativo de interesses, que fragmentou o processo de mobilização social por parte do governo. Por outro lado, contudo, o regime impôs um sentido de ordem fundado numa concepção autoritária de segurança nacional e estimulou a formação de uma burocracia capaz de dar vida política à racionalidade e à eficiência requeridas para a consecução da “reconstrução econômica, financeira, política e moral do Brasil”. ${ }^{27}$ Foi daí que resultou o mencionado autoritarismo transicional - período histórico em que, especialmente depois do Ato Institucional $\mathrm{n}^{\circ}$, os cidadãos foram desprovidos de direitos e convertidos em súditos. Em outras palavras, a ideia tradicional de um Estado representativo de feições liberais, alicerçado na participação política dos cidadãos e no embate entre partidos, cedeu lugar a um Estado de feições tecnocráticas. Ou seja, um Estado que cria e reproduz uma burocracia dotada de interesses próprios, os quais são realizados por meio de um crescente intervencionismo estatal quer no nível das relações de produção, quer no nível das relações de produção social. Um Estado que, ao desprezar a legitimidade assegurada por uma ordem legal definida a priori e ao tecer loas à legitimação pela eficiência, acabou convertendo a produção normativa arbitrária e casuística num fim em si mesmo. Em artigo jornalístico sobre o Ato Institucional n ${ }^{\circ}$, Raymundo Faoro diz:

Do alto a baixo do sistema o conceito de lei se perdeu, no seu teor liberal e democrático, para ser substituído por medidas, supostamente eficientes. Incapaz pelos próprios mecanismos do regime de organizar o consenso, separado da opinião pública e dos intelectuais, apelava-se para o único meio possível: a coerção como instância primeira de obediência [...]. A coerção, de ultima ratio, passou para o primeiro plano e se ideologizou, fora do aparelhamento parlamentar e da opinião pública, deslocando a ênfase para a defesa do sistema de 64, com suas reformas, na lembrança permanente do risco de volta ao passado. (FAORO, 1978b).

Assim, a crescente produção de leis extraordinárias, decretos, portarias e resoluções normativas conforme as conveniências e necessidades da gestão econômica multiplicou as prerrogativas de esferas administrativas até então só dotadas de estreita competência regulamentar. Por consequência, a flexibilidade e a mutabilidade dessa ordem jurídica geraram um sem-número de problemas políticos e legais, que foram muito bem explorados por uma oposição sufocada, perante uma opinião pública reprimida. O que, na contrarreação, acabou levando à ampliação do arbítrio do regime. Quanto mais maleáveis foram as normas

27 A expressão entre aspas consta do Ato Institucional $n^{\circ}$ 1, baixado em 9 de abril de 1964, e do Ato Institucional $n^{\circ} 5$, baixado em 13 de dezembro de 1968 . 
assim editadas, com a pretensão de se legitimarem pela eficiência e por resultados, maiores foram as dúvidas sobre as decisões econômicas, financeiras e administrativas tomadas. Quanto mais intervenção e controle, quanto mais medidas de emergência travestidas de atos institucionais, maior a perversão dos princípios mais elementares do constitucionalismo - e, por tabela, da legitimidade legal-racional. Nas palavras de Faoro, "as emergências, ao serem deflagradas, se conjuram perigos, levantam outros riscos, por força da própria suspensão das garantias constitucionais. Nelas estão implícitas forças ditatoriais, na sua índole profunda, que facilmente perdem o adjetivo constitucional" (FAORO, 1978a). Enfim, quanto mais a tecnocracia do regime militar transformava leis em mecanismos destinados a avançar em direção a metas específicas, iniciativa justificada em nome de uma ética de convicção, mais se desfigurava a ordem jurídica e se desprezava a ética de responsabilidade.

Foi justamente esse o ponto que Faoro escolheu como fio condutor de seu discurso na abertura do encontro anual da OAB de 1978, quando exigiu a abertura política e destacou as pressões democratizantes emanadas da sociedade. Faoro diz, nos primeiros parágrafos de sua alocução, prenunciando a densa argumentação de inspiração weberiana que a tornaria um clássico entre os textos de direito público:

No passado, quisemos a mudança e tudo mudou. Hoje, queremos a transição e queremos o que está além da transição, com o senso de responsabilidade de quem refletirá, no gesto desferido, a consequência do amanhã recomeçado e reconstruído. [...] Nascemos e vivemos envolvidos por forças que fugiram à nossa vontade e ao nosso entendimento, delas nos alheamos, incapazes de conservá-las no convívio imediato, para controlá-las e dominá-las. O Estado as abriga, com a tendência de sobrepô-las à sociedade, em armadura de ferro, numa aliança distante de detentores do Poder, se quebrado o conduto que o prende aos seus destinatários. A cidade política aliena-se da cidade comum e de todos, cidadela perdida no mundo, sem caminhos que a ela levem, só aberta a estrada que dela parte para expedir ordens. Incorporar a cidadela à cidade será nossa tarefa, desarticulando da categoria dirigente as justificações de tutela, que se expandem na onisciência tecnocrática e na onipotência da força, como se o Poder fosse apenas o mistério e a dimensão demoníaca de coisas fora do comando do homem. [...]

Nesse equívoco de atualizar o velho na promessa do longínquo dia a nascer atrás das montanhas, encartou-se uma ideologia que pretende legitimar um tipo de Estado, pela exceção, na normalidade e na rotina. O poder não se qualificaria pelo direito nessa falsa perspectiva - mas pela eficiência dos resultados e, se duvidosos os resultados, pela retomada da eficiência. Dissociou-se [...] a democracia da participação social e política. A autoridade se degradaria na força, em instância última, sem o apoio à legitimidade, conceito que alude a valores, que conferem autoridade ao sistema jurídico, para que possa ser acatada sem o imediato uso da força, em que não se 
transforme esta em apelo preliminar no exercício do governo. O acessório, se esquecido o conceito de legitimidade, ocupa o lugar do principal, quebrando a aliança entre povo e governo, convertida a lei unicamente na voluntas de quem manda sem a ratio do equilíbrio do conjunto social. A força só teria justificação se revestida de autoridade, para que o direito não seja apenas a mão do mais forte, assimilada aquela à violência.

Nos parágrafos seguintes, com sua linguagem difícil, frases elípticas, excesso de metáforas e de comparações históricas e o gosto amargo da ironia, o então presidente da OAB afirmou:

A força, para que se legitime, há de encadear-se ao poder, que por sua vez se articula à autoridade. Se o poder fosse a expedição pura de ordens, ordens circunstanciais ou ordens planejadas, sem que o concurso popular as qualifique juridicamente, tudo se reduziria ao decisionismo dos detentores do poder, abrigados embora na racionalidade formal dos meios, com amplos recursos técnicos de imposição ou de persuasão manipulada. Estar-se-ia, ao percorrer esse atalho realista, no campo do arbítrio, sem que a generalidade das leis e a igualdade de todos perante elas o condicionassem e o diluíssem. As próprias leis - leis que só o seriam em sentido impróprio - se excluído o arbítrio unicamente da técnica dos meios, poderiam ser arbitrárias. Haveria, no caso, pseudo Estado de Direito, consagrado no desordenado capricho dos governantes, mascarado nas decisões, que se transmitiriam ao ordenamento positivo composto de medidas - medidas e não leis - individuais, fora do alcance dos mecanismos corretivos de sua validade, quer por falta do consentimento popular, quer pela suspensão dos mecanismos institucionais que as legitimam.

$[\ldots]$

No momento em que as medidas individuais ocupem o lugar das leis, todo o arcabouço político se converte em ordenador e executor de decisões que, na sua substância, são policiais. Desapareceria a divisão de funções, reduzidos os tribunais a repartições administrativas, na quebra do princípio da independência do Judiciário. Alijadas essas cautelas - a generalidade da lei, a igualdade perante ela, com sua sequela básica, a separação dos poderes - a sociedade, desarmada, estaria submetida às medidas individuais do poder, individuais ainda quando dirigidas a uma coletividade, com o risco de se dissimularem ideologicamente para ludibriar a maioria.

As conclusões, no estilo e nos termos postos pelo autor, foram as seguintes:

(a) "o suposto realismo da eficiência levará à inconversibilidade dos interesses, no círculo em que o poder só conhece a dimensão da força e não a dimensão da legitimidade, capaz de qualificá-la na lei que, por ser geral e por supor a igualdade, expressa o pacto de convivência popular no estatuto político"; 
(b) "as liberdades políticas atravessaram metamorfoses que lhes infundiram conteúdo na dinâmica social; caracterizadas, em outros tempos, pela só desconfiança à sociedade política, encarnaram liberdades contra o Estado e liberdades de intervenções corretoras do equilíbrio entre fracos e poderosos, para adquirirem, ao se aperfeiçoarem, densidade de participação à formação do Estado e aos elos que articulam a sociedade civil”;

(c) "o liberalismo apenas armado contra o Estado, mostrou-se incapaz, pela feição elitista, de corporificar uma doutrina democrática de governo [...]; faltava-lhe a disposição de banhar-se nas águas, às vezes turbulentas, do rio que atravessa e inunda a cidade política";

(d) "isso não leva a admitir que as velhas liberdades morreram e outras nasceram, ao contrário do que divulgam os cartórios que periodicamente expedem certidões de óbito do liberalismo; as liberdades das declarações do século passado foram superadas - superação, atente-se, tem um cunho filosófico bem definido, que significa incorporar, negando aspectos incompatíveis com situações novas e emergentes, filiadas à efetiva participação política, social e econômica";

(e) "o Estado de Direito é um processo - a pacificação, isoladamente, não leva a ele; mas ele não se aperfeiçoa sem ela";

(f) "seria admissível a associação sindical, a reunião reivindicante e pacífica sem que, na base, estivesse a liberdade de opinião para consagrar as divergências? Banidas umas ou, na linguagem corrente, mortas - seriam as subsequentes ilusórias. Ameaçadas as últimas, sua defesa estaria, em instância válida, na garantia das primeiras. Fora daí há o cemitério inquisitorial povoado de vítimas indefesas".

Ao final do discurso, Faoro tocou num nervo exposto: o apoio dado pela OAB ao golpe militar, em abril de 1964, sob a justificativa dos juristas-políticos - de que a ordem jurídica estaria sob iminente ameaça -, e a sucessão de áulicos professores de direito de universidades públicas prestigiosas que serviram à ditadura militar e/ou ofereceram-se para formular "programas" e "doutrinas" para o novo regime. Alguns chegaram a escrever atos institucionais baixados com o objetivo de suprimir liberdades públicas e foram cúmplices do que as ditaduras têm de mais abjeto. Outros, contudo, apesar de terem atuado como interlocutores de militares e tecnocratas nos primórdios do regime, conscientizaram-se dos riscos para as garantias fundamentais da progressiva conversão do direito em instrumento de gestão econômica e reviram sua posição. Por arrependimento ou dor de consciência e, obviamente, receosos da perda de sua imagem pública, compensaram a posição anterior passando a fazer oposição extrema ao regime, reivindicando o "Estado de Direito 
Já” e não admitindo diálogo com interlocutores do governo Geisel. ${ }^{28}$ Observador atento das pacholices, irreflexões, precipitações e desacertos políticos e estratégicos dos homens vaidosos, Faoro primeiramente apontou o equívoco desse tipo de oposição radical. Em seguida, criticou, de forma contundente, os "advogados de velha mentalidade elitista formados no tempo em que quase todos os bacharéis eram parlamentares e ministros da Justiça em potencial". ${ }^{29}$ A seu ver, depois dos assassinatos de Wladimir Herzog (em 1975) e Manoel Fiel Filho (em 1976) em porões de estabelecimentos policiais e militares sob a jurisdição do então II Exército, fechar as portas para o diálogo, sob o pretexto de "não coonestar a ditadura", somente favoreceria os setores mais toscos e ferozes do regime militar. E também acabaria inviabilizando a reconquista de algumas garantias fundamentais - como o habeas corpus, cujo restabelecimento vinha exigindo e negociando com apoio de outros líderes da sociedade civil.

Em outras palavras, os riscos haviam crescido muito e qualquer passo em falso em direção à reabertura política poderia acarretar reações irreversíveis. A tese de Faoro era que não se poderia pensar no ideal - o restabelecimento da democracia sem se levar em conta o real a fratura das Forças Armadas e o enclave da chamada "linha dura". Distribuindo profusão de farpas, por um lado, e tentando alinhar politicamente os advogados, por outro, ele diz:

Dentro da névoa autoritária, acendemos a fogueira que reanima as vontades e esclarece espíritos. Estamos diante da transição inevitável e estamos diante da luz da manhã, a

Sobre os embates entre "gradualistas" e "não gradualistas" na conferência da OAB, especialmente a oposição de advogados paulistas e de professores da Faculdade de Direito da USP às posições defendidas por Raymundo Faoro, ver o depoimento de Miguel Reale Júnior em Schubsky (2007, p. 131-137).

Pouco tempo antes do encontro anual da OAB, Raymundo Faoro havia recebido - e aceitado - uma proposta de diálogo com os condutores da já mencionada estratégia de distensão política "gradual e segura" para discutir, ainda que de forma incipiente, um roteiro de transição. Três personagens representativos desses "advogados da velha mentalidade elitista" então o procuraram para persuadi-lo a recuar. Segundo eles, ao aceitar o diálogo proposto, Faoro estaria de certa forma maculando a tradição de independência da OAB. Realizado na sede da entidade, na avenida Marechal Câmara, no centro do Rio de Janeiro, o encontro foi bastante tenso, e Faoro precisou de muita diplomacia - o que nem de longe era seu forte - para levá-lo a bom termo. Os três advogados eram Miguel Seabra Fagundes, José Eduardo Prado Kelly e Evaristo de Morais Filho. Houve um quinto participante no encontro: eu, convidado por Faoro para ser sua testemunha. A advertência feita pelos três juristas na ocasião era tão improcedente quanto injusta, uma vez que Faoro, em 1972, havia agido com brio e bravura como representante da OAB no Conselho de Defesa dos Direitos da Pessoa Humana, à época em que o órgão foi coordenado pelo ministro da Justiça, Alfredo Buzaid. Além de comparar publicamente o Ato Institucional no 5 a uma "pistola engatilhada", Faoro aproveitou as reuniões do Conselho para ironizar a obsessão do ministro da Justiça em promover a reforma de alguns códigos - uma iniciativa contraditória, já que se vivia sob um estado de exceção. 
incerta, a penosa manhã de esperanças e malogros prováveis. Articulamos, filtramos e criamos mais do que ideias e perspectivas históricas, bem mais do que a utopia das declamações e da retórica festiva.

"Não há mais entre nós consciências disponíveis, prontas às transigências, às seduções do poder [...]. Nosso contingente de homens e ideias está na vanguarda" e "a mensagem é da mudança pacífica”, certa de que é possível um "compromisso sem transigências, sem concessões no campo dos princípios, com a compreensão da realidade que todos sentimos e encarnamos, realidade que não dissimula os conflitos, legitimando-os, ao contrário, no pacto que preserva a liberdade e o direito de suscitá-los”, afirmou Faoro, tentando apresentar os advogados como uma corporação reunificada.

$\mathrm{O}$ quanto suas palavras refletiam efetivamente a realidade, esta é outra história - e ele a conhecia suficientemente bem.

\section{IV}

Ousados, densos, muito longos e certamente enfadonhos, uma vez que foram originariamente preparados como discursos para eventos institucionais e políticos, os textos de San Tiago Dantas e Raymundo Faoro acima examinados discrepam das análises convencionais de Direito Público e Teoria Geral do Direito prevalecentes no país à época. Ambos tinham consciência de que seu papel era preparar o terreno, balizar caminhos e iluminar debates enquanto se esperava algo maior - novas ideias, novos projetos - capaz de formular uma convocação à vontade nacional. Ainda que não tenham alcançado repercussão e penetração imediatas, os pronunciamentos, artigos, ensaios e livros de Orlando Gomes, San Tiago Dantas e Raymundo Faoro continuam até hoje sendo decisivos para oxigenar um pensamento jurídico que, influenciado muitas vezes pelo fetichismo da legalidade e outras vezes por um humanismo vago, impreciso e inconsistente, resiste a abrir espaço para inovações temáticas e engenhosidade analítica.

Enquanto Orlando Gomes lançou o olhar para as condicionantes econômicas das instituições jurídicas, mais precisamente para a infraestrutura econômica conforme a abordagem marxista que o inspirou, San Tiago Dantas e Raymundo Faoro voltaram-se para o alcance, a efetividade e a funcionalidade do Estado de Direito, bem como para as formas de legitimação da produção normativa, numa linha de interpretação de caráter weberiano. Com afinidade temática, San Tiago e Faoro não foram os primeiros juristas a recorrer à sociologia política e à sociologia jurídica de Max Weber. Faoro, contudo, acabaria com o tempo alcançando uma influência que outros juristas não conseguiram com base nessa perspectiva teórica. San Tiago advertiu para os riscos de cesarismo (mais um conceito extraído da análise de Weber sobre os tipos e as estruturas de dominação), antevendo a eclosão do golpe militar de 1964 e as três sombrias décadas de ditadura que se seguiram a ele, enquanto Faoro apontou 
seus gargalos institucionais, políticos, éticos e morais e mobilizou sua força intelectual para tentar abreviá-la.

Para um scholar do direito, San Tiago Dantas - que morreu relativamente jovem - escreveu pouco em matéria de Teoria do Estado, Teoria do Direito e Sociologia Política, quase sempre sob a forma de aulas inaugurais no universo acadêmico e conferências pronunciadas em eventos institucionais. Seu último texto é uma síntese precisa e coerente de um pensamento interdisciplinar, inteiramente fora da curva. Por seu lado, Raymundo Faoro não foi scholar no sentido estrito do termo. Não fez pós-graduação, não escreveu teses de concurso, não lecionou, não seguiu carreira nos principais centros de pesquisa do país e não frequentou o circuito acadêmico internacional, tendo apenas passado algum tempo no Instituto de Estudos Avançados da USP e integrado poucas bancas examinadoras. ${ }^{30} \mathrm{De}-$ pois de encerrar sua gestão à frente da OAB confessando-se "decepcionado", 31 a tal ponto que não quis disputar a reeleição, acabou convertendo o discurso preparado para a VII Conferência Nacional da entidade em 1978 em base teórica e grade conceitual para outros ensaios e artigos jornalísticos sobre a mesma temática - especialmente com relação à transição política e à Assembleia Nacional Constituinte convocada em 1986. Ainda que ofuscados por suas duas obras magnas fora do campo estrito do direito, ${ }^{32}$ esses ensaios e artigos -

30 Indicado para compor a banca examinadora de livre-docência em história, na Faculdade de Filosofia, Letras e Ciências Humanas da USP, em 1975, e que tinha Carlos Guilherme Mota como candidato, Raymundo Faoro teve o nome vetado pelos catedráticos das velhas gerações, que alegaram não ter ele a devida titulação. Após acirradas discussões, o nome de Faoro só foi aprovado - e em votação muito apertada - porque os defensores de sua indicação blefaram, afirmando que ele seria "doutor por notório saber" numa das universidades públicas do Rio de Janeiro. "Ele entrou no estamento, digo na banca, graças a essa mentira. Até foi uma glória romper com o estamento, que é quase todo feito de mentiras, terras absurdas, comissões examinadoras por vezes estranhas, medalhinhas e promoção de imbatíveis mediocridades", lembra Carlos Guilherme Mota (2010, p. 148).

31 "Temos uma elite, mas ela está distanciada do povo e desligada do resto do país. Temos uma nata intelectual que se educou e formou em círculo fechado, sem vínculos com o povo. Acho que aí está a razão por que continuamos batendo na mesma tecla, cometendo os mesmos erros e repetindo os mesmos chavões. O que procurei fazer, fundamentalmente, foi uma formulação teórica para diminuir a distância entre a elite e o povo. Não sei se fui bem-sucedido, mas posso garantir que fui bem entendido", disse Faoro em entrevista ao jornal $O$ Estado de S. Paulo (edição de $1^{\circ}$ de abril de 1979), quando mencionou a decepção com a OAB. "Os homens se comportaram aquém do que esperava. Confesso que me assusto com a mediocridade com que se luta pela redemocratização”, afirmou, reconhecendo que faltou criatividade à luta pelos direitos do homem e lembrando que, apesar de ser um liberal, chegou até a ser chamado de "comunista de elite" por "advogados da velha mentalidade elitista" (FAORO..., 1979).

32 Refiro-me a Os donos do poder: a formação do patronato brasileiro, livro originariamente lançado em 1958 e reformulado e bastante expandido na edição seguinte, de 1975. E, também, a Machado de Assis: a pirâmide e o trapézio, livro lançado em 1974, em que procura analisar a originalidade da obra desse autor 
reunidos em dois pequenos livros ${ }^{33}$ - constituem um trabalho importante, formando o que Antonio Candido chamou certa vez de uma "filosofia política da vida cotidiana".34

Tendo vivido em períodos históricos de grandes mudanças econômicas, tensões sociais, impasses políticos e rupturas institucionais, Orlando Gomes, San Tiago Dantas e Raymundo Faoro configuraram - cada um em sua circunstância pessoal e intelectual - uma elite inovadora do pensamento jurídico brasileiro, capaz de pensar criticamente sobre os regimes institucional e econômico em que viviam e sobre sua própria classe social. Evidentemente, a ousadia na escolha tanto dos temas quanto das abordagens nem sempre foi correspondida em matéria de rigor metodológico, sem que isso afete seus respectivos legados intelectuais. É difícil saber, por exemplo, o quão atenta e completa foram as leituras que Gomes fez de Karl Marx ou o preço que Faoro pagou por não ter feito um mestrado ou um doutorado, o que lhe teria propiciado maior coerência e rigor metodológico. Também é difícil saber o quanto os textos de San Tiago Dantas não escondem ambições políticas inconfessadas ou expressam concessões com vistas a objetivos de poder na vida pública.

Das leituras de Marx, por exemplo, Orlando Gomes extraiu e deu o tratamento adequado às concepções de ideologia, entendida como distorção do conhecimento decorrente do dilaceramento da comunidade humana e do conflito de classes, e de história, vista como um processo contraditório no qual os homens dominam as forças da natureza, mas fraturam a comunidade, lançando os indivíduos e os grupos uns contra os outros numa competição desenfreada pelo lucro. Mas não explorou o suficiente a concepção marxista de homem como um ser que se faz a si mesmo pelo trabalho, o que lhe teria permitido analisar com maior profundidade as condições de exploração e aviltamento do trabalho e seu impacto na degradação da criatividade humana, dentro de um sistema que reduz tudo a mercadoria. Também teria faltado a Gomes uma compreensão mais elaborada da estrutura interna do Estado - mais precisamente, da estrutura dos interesses da sociedade e dos mecanismos que fazem a mediação entre esses interesses, por um lado, e as decisões governamentais e a produção legislativa, por outro. Além disso, determinados termos utilizados pelo jurista baiano - como desenvolvimento e humanização, por exemplo - careceriam de contornos mais bem definidos, lembram seus biógrafos. E algumas argumentações não decorreriam de análises históricas profundas ou de fundamentos empíricos, mas de "uma boa dose de intuição" (RAMOS; SILVA FILHO, 2015, p. 121).

e a vida que ele infundiu a seus personagens no cotidiano social da capital do país no final do século 19 e a percepção do funcionamento das instituições, como família, Estado e Igreja.

33 Trata-se dos livros Assembleia Constituinte: a legitimidade recuperada (1986) e Existe um pensamento político brasileiro? (1994). 
Já San Tiago Dantas, que, por ter sido um influente deputado federal e ministro operante, conhecia muito bem as estruturas internas da máquina governamental e as entranhas do poder, talvez tenha pecado em seus escritos, notadamente em seu último e histórico discurso, por conceber e/ ou tratar o Estado como uma entidade homogênea, coesa e altamente articulada - quando, na realidade, o Estado brasileiro se encontrava à época internamente fragmentado em anéis burocráticos, ou seja, dividido em várias arenas que se associavam a diferentes blocos de interesses, muitas vezes incongruentes entre si. Na medida em que os múltiplos centros de decisão dividiam lealdades em torno de demandas, propostas e projetos distintos, aponta um analista da crise política e da paralisia decisória dos primeiros anos da década de 1960 (ABRANCHES, 1987), o Estado brasileiro tinha comprometidas a homogeneidade das políticas públicas, a coerência global de suas decisões e a própria capacidade de planejar, de definir orientações e estabelecer metas de longo prazo e de enfrentar questões estratégicas - como é o caso, por exemplo, da questão social, que foi tão enfatizada por San Tiago no discurso pronunciado no Hotel Glória.

Com relação a Raymundo Faoro, advogado formado no final da década de 1940 pela Universidade Federal do Rio Grande do Sul e que se transferiu para a cidade do Rio de Janeiro na década seguinte, lançando em 1958 a primeira edição de Os donos do poder por uma editora regional e ainda relativamente desconhecido do ambiente acadêmico e dos centros urbanos mais desenvolvidos do país, como o Distrito Federal e São Paulo, ${ }^{35}$ não passou despercebido do crivo de um dos mais conhecidos e importantes críticos literários da época. Trata-se de Wilson Martins, professor de literatura da New York University, autor de História da inteligência brasileira, ganhador dos prêmios Jabuti e da Academia Brasileira de Letras e colunista, por sucessivas décadas, dos cadernos de cultura do Jornal do Brasil e de $O$ Estado de S. Paulo. De forma sutil e educada, Martins apontou descuidos acadêmicos e cobrou um certo provincianismo.

A exata apreciação de seus pontos de vista é um pouco dificultada pela falta de clareza, ideológica e de expressão, que, em conjunto, caracteriza seu livro. O jovem ensaísta, cuja seriedade intelectual é das mais estimáveis, parece não haver estabelecido preliminarmente, com a nitidez indispensável, as grandes linhas de seu estudo, a tal qual lecionavam Álvaro Vieira Pinto, Hélio Jaguaribe e Alberto Guerreiro Ramos, discutia o nacionaldesenvolvimentismo e as diferentes versões da teoria da dependência. E, também, a São Paulo, onde um grupo de professores de filosofia, sociologia e ciência política da USP, liderados por José Arthur Giannotti, Fernando Henrique Cardoso e Fernando Novais, criaram o chamado Grupo do Capital, ou o Seminário Marx, com o objetivo de estudar a obra do filósofo e sociólogo alemão com rigor metodológico e em perspectiva interdisciplinar - ao contrário do que se fazia até então. Ver Rodrigues (2011) e Toledo (1998). 
ponto que, no desenvolvimento cronológico do tema, não se percebe a mudança das circunstâncias históricas. (MARTINS, 1959).

Isso e a falta do devido rigor com relação a minúcias históricas

tornam penosa a leitura, uma vez que a história e a crítica histórica compõem-se, ao mesmo tempo, de pormenores e análises globais - de análises globais tanto mais seguras e indestrutíveis quanto mais rigorosamente exatos forem os pormenores de fato em que se assentarem. (MARTINS, 1959).

$\mathbf{V}$

"O destino de uma faculdade é o destino do direito a que ela serve" - disse San Tiago Dantas em sua já mencionada aula inaugural de 1955. Insensível às observações de Orlando Gomes, de San Tiago e de Raymundo Faoro entre as décadas de 1950 e 1970, o ensino jurídico brasileiro permaneceu incapaz de absorver as demandas econômicas e sociais das décadas seguintes, condicionado que estava por uma dogmática erigida com base num positivismo mais ideológico do que metodológico - e que tende a se confundir com o legalismo ao tomar o direito positivo como objeto exclusivo da análise jurídica. Décadas essas que culminaram num processo de abertura econômica, de integração dos mercados em escala global, de internacionalização das cadeias produtivas e de desmaterialização da economia, como decorrência da inovação tecnológica, do acesso imediato à informação e da progressiva transferência do investimento físico para a imaginação e criatividade, em matéria de criação de valor.

Com um professorado desprovido de autocrítica e apegado a preconceitos doutrinários, políticos e ideológicos, o ensino jurídico não acompanhou a expansão qualitativa da pesquisa científica em ciências humanas no decorrer das últimas décadas. Mesmo com o novo cenário, continua dependente de um currículo formulado com base numa concepção de direito que defende a unidisciplinariedade do conhecimento jurídico - portanto, voltado aos estudos de reprodução dos institutos jurídicos, não para sua crítica. Prossegue sendo um centro de transmissão de um conhecimento jurídico oficial, voltado ao exercício de uma advocacia convencional e insensível quer para a chamada advocacia pública estruturante, quer para a advocacia de interesses sociais complexos. Pouco criativo, desenvolveu mecanismos de autodefesa e resistência, como reconhecem as agências de fomento à pesquisa em seus diagnósticos, limitando-se a reproduzir, contínua e confortavelmente, a sabedoria codificada e a cultivar relações cerimoniosas com as instituições que aplicam o direito positivo.

A excessiva ênfase dos cursos jurídicos sobre o papel do direito positivo como instrumento de controle político e social tem impedido os alunos de perceber a velocidade e o alcance do processo schumpeteriano de destruição criadora e de identificar as novas formas de poder, o advento de soberanias compartilhadas e de sistemas autônomos e funcionalmente 
diferenciados com alcance mundial e o esgotamento da funcionalidade da política legislativa tradicional. Insensível aos imperativos de um mundo post westafaliano que se caracteriza pela desvinculação entre jurisdição e território, entre Estado e política, o ensino jurídico desestimula um raciocínio jurídico dos problemas contemporâneos voltado para o diálogo interdisciplinar com a economia, a sociologia, a ciência política, a antropologia e as relações internacionais. Ou seja, um raciocínio desenvolvido com rigor analítico, precisão conceitual, cuidado metodológico e pertinácia analítica.

Num contexto político-institucional de crescente policentrismo decisório e numa sociedade cada vez mais organizada em redes, relações de interdependência e instantaneidade comunicativa, em cujo âmbito o fator decisivo para a criação de valor foi transferida do investimento físico para a imaginação e a criatividade, duas perguntas se fazem necessárias. Em primeiro lugar, de que modo formar novos juristas fora da curva se o universo intelectual dos nossos cursos jurídicos continua bastante estreito, limitado e frustrante? Em segundo, se estivessem vivos, Orlando Gomes, San Tiago Dantas e Raymundo Faoro encontrariam hoje nas faculdades de direito e nas corporações de operadores jurídicos do país interlocutores com a mesma envergadura cultural para dialogar? Da maneira como foram formuladas, as indagações já entreabrem a resposta.

O desprezo às advertências desses três juristas fora da curva, cuja linhagem a meu ver não teve herdeiros, é assim um equívoco histórico de grandes proporções - fato já detectado por sucessivos documentos de avaliação e perspectiva da área do direito elaborados por agências de fomento à pesquisa, como o Conselho Nacional de Desenvolvimento Científico e Tecnológico ( $\mathrm{CNPq})$. A teoria jurídica não acompanhou o desenvolvimento socioeconômico, contentando-se em trabalhar com categorias tradicionais e modelos fechados. Magistrados passaram a decidir como se fossem doutrinadores - mas produzindo judicialmente uma doutrina sem maior rigor e qualidade. Professores de direito positivo limitaram-se a comentar sua convivência casuística com os que decidem. A pesquisa desprezou as questões relativas aos fundamentos das leis e ignorou conflitos sociais e processos legislativos. Acima de tudo, as faculdades de direito mantiveram-se distantes das demais escolas da área de ciências humanas. Como era inevitável, pagaram o preço do isolamento, esquecendo-se de que, quando não produzem o que ensinam e o que se pretende ensinar não reflete o conhecimento produzido, a Ciência do Direito não consegue avançar. Com isso, o pensamento jurídico tende a se renovar e avançar por meio de outras unidades e órgãos geradores de conhecimento - inclusive as faculdades de economia e os cursos de filosofia, sociologia política e antropologia. Do mesmo modo, a pesquisa tende a se deslocar para centros mais autônomos, desburocratizados e interdisciplinares. ${ }^{36}$ 


\section{NOTA DE AGRADECIMENTO}

$A$ ideia deste texto surgiu quando o professor Cícero Romão de Araújo, do Departamento de Ciência Política da Universidade de São Paulo (USP), convidou-me para fazer uma exposição no Centro de Estudos de Cultura Contemporânea (Cedec) sobre o perfil jurídico de Raymundo Faoro e as ligações que tivemos, eu como jornalista e ele como presidente da $O A B$. Ao reabrir meu arquivo, deparei-me com anotações de antigas leituras de autores que marcaram minha formação, como Orlando Gomes e San Tiago Dantas, além do próprio Faoro. Meu objetivo não foi estudar a obra completa dos três, mas apenas alguns de seus textos, numa escolha absolutamente pessoal - portanto, arbitrária. Agradeço a Celso Campilongo, José Reinaldo de Lima Lopes, Ronaldo Porto Macedo Júnior, Jean Paul Cabral Veiga da Rocha, Emerson Ribeiro Fabiani, CamilaVillard Duran, Pedro Dutra e Osny da Silva Filho as críticas e sugestões recebidas durante a elaboração deste texto.

\section{REFERÊNCIAS BIBLIOGRÁFICAS}

ABRANCHES, Sérgio Henrique. Governo, empresa estatal e política siderúrgica: 1930-1975. In: ; LIMA JR., Olavo Brasil de (Orgs.). Estado autoritário e planejamento no Brasil. Rio de Janeiro: Iuperj, 1987.

ABREU, Marcelo de Paiva. Crise, crescimento e modernização autoritária: 1930-1945. In:

(Org.). A ordem do progresso: cem anos de política econômica republicana. 1889-1989. Rio de Janeiro: Campus, 1989a.

Inflação, estagnação e ruptura: 1961-1964. In: (Org.). A ordem do progresso: cem anos de política econômica republicana. 1889-1989. Rio de Janeiro: Campus, 1989b.

ADORNO, Sérgio. Os aprendizes do poder: o bacharelismo liberal na política brasileira. São Paulo: Paz e Terra, 1988. 
BAER, Werner; KERSTENETZKY, Isaac; VILLELA, Annibal. As modificações no papel do Estado na economia brasileira. Pesquisa e Planejamento Econômico, Ipea, v. 3, n. 4, p. 883-912, 1973.

BASTOS, Aurélio Wander. O Estado e a formação dos currículos jurídicos do Brasil. In: (Coord.). Os cursos jurídicos e as elites políticas brasileiras. Brasília: Câmara dos Deputados, 1978. Pesquisa jurídica: diagnósticos e perspectivas. Sequência, Florianópolis, v. 23, p. 11-21, 1991.

BIELSCHOWSKY, Ricardo. Pensamento econômico brasileiro: o ciclo ideológico do desenvolvimentismo (1930-1964). Rio de Janeiro: Ipea, 1988.

CAMPILONGO, Celso Fernandes. Assistência jurídica e realidade social: apontamentos para uma tipologia dos serviços legais. In: ; PRESSBURGER, Miguel. Discutindo a assessoria popular. Rio de Janeiro: Ajup/Fase, 1991. p. 8-28. (Coleção Seminários, n. 15).

CAMPOS, Roberto; SIMONSEN, Mário Henrique. A nova economia brasileira. Rio de Janeiro: José Olympio, 1974.

CARDOSO, Fernando Henrique. Aspectos políticos do planejamento. In: MINDLIN, Betty (Org.). Planejamento no Brasil. São Paulo: Perspectiva, 1970.

COMPARATO, Fábio Konder. Raymundo Faoro historiador. Estudos Avançados, São Paulo, USP, v. 17, n. 48, p. 330-7, 2003.

CONSELHO NACIONAL DE DESENVOLVIMENTO CIENTÍFICO E TECNOLÓGICO (CNPq). Desenvolvimento científico e formação de recursos humanos, 1980-1984. Brasília, 1984.

DANTAS, Francisco Clementino de San Tiago. Conflito de vizinhança e sua composição. 1939. Tese Faculdade Nacional de Direito, 1939. A educação jurídica e a crise brasileira. Revista Forense, Rio de Janeiro, n. 159, 1955.

. Visconde de Cairu, protagonista de sua época. In: Figuras do Direito. Rio de Janeiro: José Olympio, 1962.

Renovação do direito. In: Encontros da UnB: ensino jurídico. 1978-1979. Brasília: Ed. da UnB, 1979. 
DISCURSO de agradecimento pelo prêmio "Homem de Visão de 1963”. Revista Brasileira de História, São Paulo, v. 24, n. 47, p. 329-338, 2004.

DUTRA, Pedro. San Tiago Dantas: a razão vencida. São Paulo: Singular, 2014.

FAORO, Raymundo. A sombra do arbítrio. O Globo, 19 jun. 1978a.

Só a nação poderá sepultar o Ato 5. O Estado de S. Paulo, 13 dez. 1978b. . Assembleia Constituinte: a legitimidade recuperada. São Paulo: Brasiliense, 1986. Existe um pensamento político brasileiro? São Paulo: Ática, 1994.

FAORO, em nome da lei. Jornal da Tarde, 6 mai. 1978. Entrevista concedida a José Eduardo Faria.

FAORO sai, decepcionado. O Estado de S. Paulo, $1^{\circ}$ abr. 1979. Entrevista concedida e Magda de Almeida.

FARIA, José Eduardo. Direito, modernização e autoritarismo: mudança socioeconômica vs. liberalismo jurídico. 1981. Tese (Doutorado em Filosofia, Teoria e Sociologia do Direito) - Faculdade de Direito, USP, São Paulo, 1981.

FURTADO, Celso. Política econômica e reformas de base. O Estado de S. Paulo, 14 de junho de 1962. Brasil - a situação pré-revolucionária. O Estado de S. Paulo, 31 mar. 1963.

GOMES, Orlando. A evolução do direito privado e o atraso da técnica jurídica. In: A crise do direito. São Paulo: Max Limonad, 1955.

Direito e desenvolvimento. Salvador: Ed. Universidade Federal da Bahia, 1961.

GUDIN, Eugênio; SIMONSEN, Roberto. A controvérsia do planejamento na economia brasileira. Rio de Janeiro: Ipea, 1977.

INNERARITY, Daniel. El diálogo entre saber y poder. Claves de Razón Practica, Madrid, n. 209, 2011.

KLEIN, Lúcia; FIGUEIREDO, Marcus. Legitimidade e coação no Brasil pós-64. Rio de Janeiro: ForenseUniversitária, 1979. 
MANNHEIM, Karl. Liberdade, poder e planificação democrática. São Paulo: Mestre Jou, 1972.

MARTINS, Wilson. A velha classe. O Estado de S. Paulo, 25 de abril de 1959. Suplemento Literário.

MINDLIN, Betty. O conceito de planejamento. In: (Org.). Planejamento no Brasil. São Paulo: Perspectiva, 1970.

MOMMSEM, Wolfgang. The Age of Bureaucracy. New York: Harper \& Row, 1974.

MOTA, Carlos Guilherme. História e Contra-História. Rio de Janeiro: Globo, 2010.

RAMOS, Luiz Felipe Rosa; SILVA FILHO, Osny da. Orlando Gomes. Rio de Janeiro: Elsevier, 2015. (Coleção Para Entender).

REALE JÚNIOR, Miguel. Depoimento. In: SCHUBSKY, Cássio (Org.). Estado de Direito Já! São Paulo, Lettera.doc, 2007. p. 131-137.

RODRIGUES, Lidiane Soares. A produção social do marxismo universitário em São Paulo: mestres, discípulos e "um seminário". 2011. 565 p. Tese (Doutorado em História Social) - Faculdade de Filosofia, Letras e Ciências Humanas, FFLCH-USP, São Paulo, 2011.

SANTOS, Wanderley Guilherme dos. Paradigma e História: a ordem burguesa na imaginação social brasileira. In: . Ordem burguesa e liberalismo político. São Paulo: Duas Cidades, 1978a, p. $18-57$.

Poder e política: crônica do autoritarismo brasileiro. Rio de Janeiro: Forense-Universitária, 1978b.

. Cidadania e justiça: a política social na ordem brasileira. Rio de Janeiro: Campus, 1979.

O ex-Leviatã brasileiro: do voto disperso ao clientelismo concentrado. Rio de Janeiro: Civilização Brasileira, 2006.

SCHLUCHTER, Wolfgang. The Rise ofWestern Rationalism. Berkeley: University of California Press, 1982.

TOLEDO, Caio Navarro de. ISEB: fábrica de ideologias. Campinas: Ed. Unicamp, 1998.

VENÂNCIO FILHO, Alberto. Das Arcadas ao bacharelismo. São Paulo: Perspectiva, 1983. 
VIANNA, Luiz Werneck. A OAB como intelectual ou coletivo. In: Ensaios sobre política, direito e sociedade. São Paulo: Hucitec, 2015.

José Eduardo Faria

Professor titular da Faculdade de Direito da Universidade de São Paulo (USP). Chefe do Departamento de Filosofia e Teoria Geral do Direito. FoI um dos ganhadores do PrÊMIO JABUTI NA ÁREA DE DIREITO, EM 2012.

jose.farialdestadao.com 